IF Sér. Reg. n. 53 p. 5-42 jun. 2015

http://dx.doi.org/10.4322/ifsr.2015.001

ISSN impresso 0103-3360/on-line 2179-2372

\title{
A VEGETAÇÃo dA ESTAÇÃo ECOLÓGICA dE AVARÉ: SUBSÍDIOS PARA O PLANO DE MANEJO
}

\section{VEGETATION OF AVARÉ ECOLOGICAL STATION: SUPPORT FOR THE MANAGEMENT PLAN}

\author{
Roque CIELO-FILHO',3; João Batista BAITELLO²; \\ Frederico Alexandre Roccia Dal Pozzo ARZOLLA²; Francisco Eduardo Silva Pinto VILELA²; \\ Marina Mitsue KANASHIRO²; Isabel Fernandes de Aguiar MATTOS; \\ Osny Tadeu de AGUIAR²; Silvana Cristina Pereira Muniz de SOUZA²; João Aurélio PASTORE²; \\ Geraldo Antonio Daher Corrêa FRANCO²; Léo ZIMBACK ${ }^{2}$
}

\begin{abstract}
RESUMO - A Estação Ecológica de Avaré é uma unidade de conservação com 720,4 ha localizada no município de Avaré, sudoeste do Estado de São Paulo. O presente trabalho apresenta os resultados dos estudos sobre o tema vegetação elaborados para o seu Plano de Manejo. Com base na análise de dados primários e secundários e de fotografias aéreas, a cobertura vegetal foi caracterizada e uma proposta de zoneamento foi elaborada. Dados primários e secundários totalizaram 265 espécies de plantas vasculares, cinco delas apresentado algum grau de ameaça de extinção: Anemopaegma arvense, Cedrela fissilis, Clitoria densiflora, Machaerium villosum e Rourea pseudospadicea. Foram identificadas cinco formações vegetais, sendo três pertencentes ao bioma Cerrado e duas pertencentes ao bioma Mata Atlântica compreendendo, respectivamente, $72,17 \%$ e 24,63\% da área da Estação. Entre as fisionomias de Cerrado, destaque pode ser dado às savânicas e campestres, que juntas ocupam 49,91\% da Estação, acentuando a sua significância devido à representatividade relativamente elevada do componente não arbóreo do Cerrado nessas fisionomias, o qual é tido como o mais rico em espécies vegetais no bioma. Três espécies invasoras foram amostradas, o pinus (Pinus sp.), o capim-gordura (Melinis minutiflora) e a braquiária (Urochloa brizantha), sendo esta última a que representa maior ameaça para a diversidade florística da Unidade. Na proposta de zoneamento preliminar, a Zona de Recuperação foi a mais expressiva, totalizando 84,81\% da área total da Unidade, onde o manejo enfatiza o controle de gramíneas invasoras.
\end{abstract}

Palavras-chave: Cerrado; Mata Atlântica; unidade de conservação; zoneamento.

\begin{abstract}
Avaré Ecological Station is a protected area with 720.4 ha located in the municipality of Avaré, southwestern São Paulo state. This study presents the results of the vegetation survey made for its Management Plan. Based on primary and secondary data and on aereal photographs analysis, the vegetation cover was characterized and a zoning proposal was elaborated. Primary and secondary data totaled 265 vascular plant species, of which five presented some degree of extinction risk: Anemopaegma arvense, Cedrela fissilis, Clitoria densiflora, Machaerium villosum and Rourea pseudospadicea. Five plant formations were identified, three belonging to the Brazilian Savanna biome and two belonging to the Atlantic Forest biome occupying, respectively, $72.17 \%$ e $24.63 \%$ of the Station area. Among the Savanna physiognomies, highlight can be given to the grassland type ones, which occupied $49.91 \%$ of the Station, reinforcing its significance due to relatively height representativeness of the non-arboreal component in these physiognomies, which is considered as the richest component in plant species in the biome. Three invading species were sampled, the pine (Pinus sp.) and the grasses Melinis minutiflora and Urochloa brizantha, being the last the uppermost threat for the floristic diversity of the area. In the preliminary zoning the Recuperation Zone was the most expressive, making up $84.81 \%$ of the total area, where the management emphasizes the control of invasive grasses.
\end{abstract}

Keywords: Atlantic forest; Brazilian savanna; protect area; zoning.

${ }^{1}$ Recebido para análise em 28.11.14. Aceito para publicação em 25.05.15. Publicado em 15.06.2015.

${ }^{2}$ Instituto Florestal, Rua do Horto, 931, 02377-000 São Paulo, SP, Brasil.

${ }^{3}$ Autor para correspondência:Roque Cielo Filho - roque@if.sp.gov.br 


\section{INTRODUÇÃO}

A Estação Ecológica de Avaré é uma unidade de conservação de proteção integral com cobertura vegetal natural composta predominantemente por vegetação de Cerrado. O bioma Cerrado é considerado uma das ecorregiões mais ricas e ameaçadas do planeta (Mittermeier et al., 2005), com taxa de endemismo de 44\% para plantas vasculares (Klink e Machado, 2005) e um total de 12.356 espécies de plantas herbáceas, arbustivas, arbóreas e cipós (Mendonça et al., 2008). Ocupando aproximadamente 21\% do território nacional (Aguiar et al., 2004), o Cerrado, em sua maior extensão, está localizado no Planalto Central, abrangendo quase integralmente os estados de Goiás, Tocantins e o Distrito Federal, além de parte dos estados da Bahia, Ceará, Maranhão, Mato Grosso, Mato Grosso do Sul, Minas Gerais, Piauí, Rondônia e São Paulo; e ocorrendo de forma disjunta nos estados do Amapá, Amazonas, Pará, Roraima e Paraná (Ribeiro e Walter, 2008).

Mais de $55 \%$ da área original do Cerrado já foi convertida em pastagem, agricultura, florestas plantadas, áreas urbanas e outros tipos de uso do solo (Klink e Machado, 2005). O percentual da área de Cerrado ocupada por unidades de conservação de proteção integral é de apenas 2,48\% (Arruda et al., 2008). De acordo com Kronka et al. (1998), no Estado de São Paulo a redução das áreas de Cerrado no período de 1962 a 1992 foi de 87\%, tendo como principais causas a expansão das lavouras de cana-deaçúcar, silvicultura, pastagens e da citricultura. Kronka et al. (2005) reportaram uma área remanescente de Cerrado de 210.074 ha, ou seja, menos de 1\% da superfície total do Estado.

Dos 1.676.300 ha da bacia hidrográfica do Médio Paranapanema, onde se encontra a Estação Ecológica de Avaré, a cobertura de vegetação natural remanescente corresponde a 6,4\% ou 107.326 ha, dos quais 31.457 ha (29\%) correspondem a áreas de Cerrado (Kronka et al., 2005). Segundo os autores, a cobertura vegetal remanescente na bacia é composta predominantemente por Floresta Estacional Semidecidual, compreendendo 2,9\% da sua superfície; as diferentes fisionomias de Cerrado e o contato Cerrado/Floresta Estacional Semidecidual abrangem, respectivamente, 1,9\% e $1,2 \%$ da área total da bacia e o restante da cobertura vegetal natural é composto por vegetação de várzea. Na região, o município de Avaré é o que apresenta a maior cobertura de vegetação nativa, com 9.332 ha, dos quais mais de 2.300 ha correspondem à vegetação de Cerrado.

Dos 839 fragmentos de Cerrado remanescentes na bacia do Médio Paranapanema, 493 apresentam área igual ou inferior a 20 ha e 73 apresentam área acima de 100 ha (Kronka et al., 2005). Portanto, a vegetação natural que ocupa a quase totalidade dos 720,4 ha da Estação Ecológica de Avaré constitui um dos mais importantes remanescentes no cenário regional. As unidades de conservação de proteção integral mais próximas são as Estações Ecológicas de Angatuba, Paranapanema e Santa Bárbara, esta última, a menos distante, localiza-se a aproximadamente 42 km da Estação Ecológica de Avaré.

Os levantamentos de vegetação constituem uma das principais fontes de informação para a execução de planos de manejo e compreendem o mapeamento dos tipos vegetacionais e a sua caracterização fisionômica e florística, incluindo a identificação de espécies ameaçadas, raras, exóticas e invasoras. Essas informações são usadas para definir estratégias de manejo, indicando zonas potenciais para os diferentes usos definidos pelo Sistema Nacional de Unidades de Conservação (Brasil, 2000a). O presente documento apresenta os resultados dos estudos sobre o tema vegetação elaborados no contexto do Plano de Manejo da Estação Ecológica de Avaré que, juntamente com as informações referentes ao tema fauna, comporão a caracterização biótica da Unidade. 


\section{MATERIAL E MÉTODOS}

\section{1 Área de Estudo}

A Estação Ecológica de Avaré - EEcA, criada por meio do Decreto Estadual $\mathrm{n}^{\mathrm{o}}$ 56.616, de 28 de dezembro de 2010, situa-se no município de Avaré (SP) (São Paulo, 2010), entre as coordenadas geográficas $22^{\circ} 56^{\prime}$ e $23^{\circ} 12^{\prime} \mathrm{S}$ e $48^{\circ} 40^{\prime}$ e $48^{\circ} 56^{\prime} \mathrm{W}$ (Figura 1). Sua área atual é de 720,4 ha. A temperatura média mensal no município de Avaré é de $20,3{ }^{\circ} \mathrm{C}$ com precipitação média anual de $1.274 \mathrm{~mm}$ e clima classificado como Cwa de Köppen, mesotérmico com inverno seco e verão quente (Sentelhas et al., 2010).

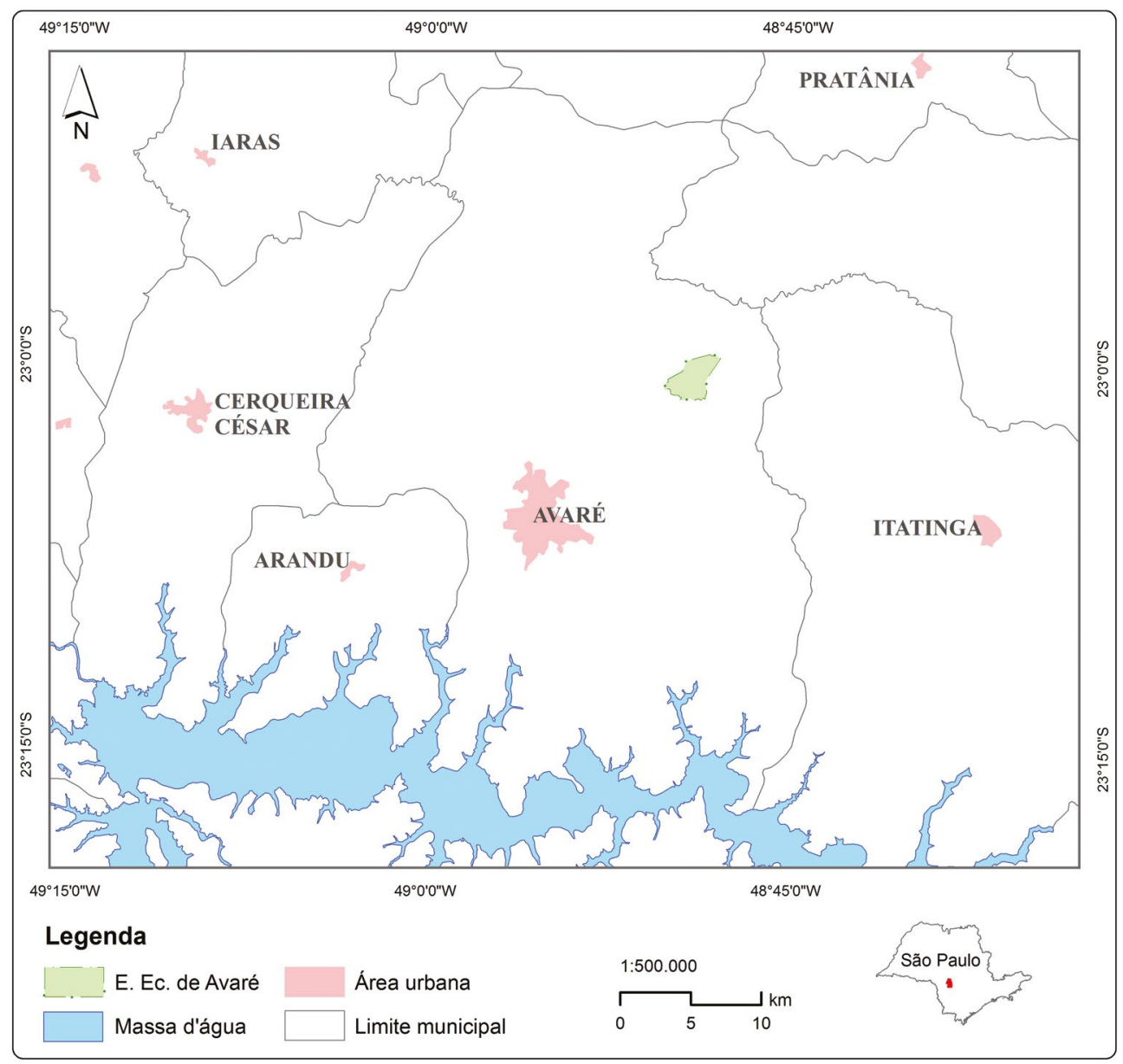

Figura 1. Localização da Estação Ecológica de Avaré (antigo Horto Florestal Andrada e Silva).

Figure 1. Localization of the Avaré Ecological Station (earlier "Andrada e Silva” forest farm).

As altitudes variam entre 700 e $803 \mathrm{~m}$, sendo parte dos limites da Unidade justapostos ou próximos ao rio Novo, ao sul, e ao córrego Água da Canela, a nordeste, ambos afluentes do rio Pardo (Silva e Kanashiro, 2010). O relevo predominante é o de Colinas Amplas, com o embasamento geológico das porções mais elevadas constituído por arenitos da Formação Marília e, nas porções menos elevadas, por basaltos da formação Serra Geral (Instituto de Pesquisas Tecnólogicas do Estado de São Paulo - IPT, 1981).

O Horto Florestal Andrada e Silva, antiga denominação da recente Estação Ecológica, foi ocupado antes da década de 1960 por reflorestamento de eucalipto, após a extração integral das fisionomias de Cerrado e da quase totalidade da Floresta Estacional Semidecidual preexistentes. O reflorestamento foi explorado por meio de desbastes e cortes rasos ao longo de algumas décadas até o ano de 2010. 
Com o passar do tempo, as espécies da vegetação primitiva foram ocupando os espaços disponíveis após os desbastes e, finalmente, após os cortes rasos dos talhões, ampliaram o processo de repovoamento desses ambientes. Esse processo de reocupação transformou a área em um grande mosaico, com os tipos vegetacionais primitivos em diferentes estádios de regeneração. A área já tem pelo menos 50 anos de processo de regeneração, tornando-se um mosaico de Cerrado lato sensu e Floresta Estacional Semidecidual.

\subsection{Obtenção de Dados Secundários}

A avaliação dos dados secundários foi dirigida à compilação dos registros de espécies vegetais disponíveis para a EEcA e ao diagnóstico de lacunas de conhecimento da produção científica sobre a composição florística na Unidade. Como referência para a compilação dos dados foram utilizados os registros em herbários e estudos em nível de comunidade.

Para este levantamento utilizou-se a base de dados do Species Link (2014). Foram considerados apenas os registros que mencionassem no campo "localidade e notas"que a coleta havia sido realizada na EEcA ou no Horto Florestal Andrada e Silva.

Os estudos realizados no nível de comunidade (levantamentos florísticos e fitossociológicos), provenientes das seguintes fontes foram considerados:

- $\quad$ projetos cadastrados na Comissão Técnico-Científica - COTEC do Instituto Florestal;

- publicações técnicas e científicas disponíveis nas bibliotecas de universidades, nos centros e institutos de pesquisa e em bases de dados disponíveis na internet (BDT, SinBiota, ISI, SciELO e outros), e

- dados não publicados (relatórios técnicos, dissertações de mestrado e teses de doutorado).

\subsection{Obtenção de Dados Primários}

Para obtenção dos dados primários foram realizadas quatro campanhas de campo, com duração de três dias cada, em março e setembro de 2010 e abril e junho de 2014. A amostragem foi baseada no método de caminhamento (Filgueiras et al., 1994). As trilhas percorridas foram definidas por meio de análise de mapa da cobertura vegetal preliminar (Arzolla et al., 2010) de modo a contemplar as diferentes fitofisionomias da Estação, permitindo amostrar os ambientes de Cerrado e de Floresta Estacional Semidecidual presentes na área, bem como contribuir para o refinamento da delimitação fisionômica obtida por meio da fotointerpretação. A delimitação fitofisionômica e a nomenclatura utilizada deram-se com base em Coutinho (1978), Ribeiro e Walter (2008) e Instituto Brasileiro de Geografia e Estatístca - IBGE (2012).

O material botânico foi coletado e herborizado, conforme Fidalgo e Bononi (1984), e depositado no Herbário Dom Bento José Pickel (SPSF) do Instituto Florestal. A identificação deu-se por meio de consulta à bibliografia, comparação em herbários e consulta a especialistas. O sistema de classificação taxonômico utilizado para as famílias foi o "Angiosperm Phylogeny Group" III (Souza e Lorenzi, 2012) e a verificação dos nomes das espécies com base em Tropicos do Missouri Botanical Garden (Missouri Botanical Garden - MOBOT, 2014), Checklist das Spermatophyta do Estado de São Paulo (Wanderley et al., 2011) e Lista de Espécies da Flora do Brasil (Forzza et al., 2015). Esta última lista também foi utilizada para verificação dos hábitos das espécies.

\subsection{Mapeamento}

O mapeamento da vegetação foi realizado por meio da interpretação visual de ortofotos digitais com resolução espacial de $1 \mathrm{~m}$, do Projeto de Atualização Cartográfica do Estado de São Paulo - Mapeia São Paulo, cedidas pela Empresa Paulista de Planejamento Metropolitano EMPLASA (08/06/2010 e 13/06/2010), e de trabalhos de campo. As informações obtidas no processo de fotointerpretação, realizada de acordo com os procedimentos adotados por Lueder (1959) e Spurr (1960), foram digitalizadas utilizando-se o Sistema de Informação Geográfica - SIG ArcMap e transportadas para a base cartográfica do Instituto Brasileiro de Geografia e Estatística - IBGE, Folhas Avaré (SF-22-Z-D-II-1) e Rio Palmital (SF-22-Z-B-V-3), na escala 1:50.000 do ano de 1973. 


\subsection{Análise Consolidada da Composição Florística a Partir de Dados Primários e Secundários}

As listas de espécies obtidas a partir de dados primários e secundários foram reunidas em um banco de dados único, a partir do qual foram verificadas as espécies raras, ameaçadas, exóticas e invasoras registradas na EEcA, bem como a distribuição da riqueza de espécies entre famílias, gêneros e hábitos de crescimento. A distribuição da riqueza entre as fitofisionomias foi feita com base apenas nos dados primários, pois a informação quanto à fisionomia onde foi realizada a coleta nem sempre está disponível nos registros de dados secundários.

Após a consolidação dos dados primários e secundários, verificou-se a ocorrência das espécies em alguma das categorias de ameaça definidas nas listas de espécies ameaçadas de extinção das seguintes fontes:

- $\quad$ Lista Oficial de Espécies Ameaçadas de Extinção no Estado de São Paulo (SMA-SP). Resolução SMA 48, de 21 de setembro de 2004 (São Paulo, 2004);

- Lista Nacional Oficial de Espécies da Flora Ameaçadas de Extinção (MMA). Portaria no 443, de 17 de dezembro de 2014 (Brasil, 2014), e

- Lista Vermelha de Espécies Ameaçadas de Extinção da União Internacional para a Conservação da Natureza (União Internacional para a Conservação da Natureza e dos Recursos Naturais - IUCN, 2014).

Para a elaboração das duas primeiras listas, as categorias e critérios adotados pela IUCN foram adaptados para a realidade brasileira e do Estado de São Paulo. As categorias utilizadas pela IUCN são, em ordem decrescente de grau de ameaça (IUCN, 2001): Extinta (EX); Extinta na Natureza (EW); Criticamente Ameaçada (CR); Ameaçada (EN); Vulnerável (VU); Baixo Risco (LR). A categoria LR é subdividida em: Dependente de Conservação (LR/cd); Quase Ameaçada (LR/nt); Menor Preocupação (LR/lc). Essa categoria não foi considerada no presente trabalho. A lista MMA oficializou a lista apresentada por Martinelli e Moraes (2013).

Além das listas de espécies ameaçadas, foi também consultada a lista de plantas raras do Brasil, segundo Conservação Internacional - Brasil (CI-Brasil) (Giulietti et al., 2009).

Foram consideradas como espécies exóticas aquelas de ocorrência fora dos limites geográficos historicamente reconhecidos (Ziller, 2001) e para espécie invasora utilizou-se a definição apresentada pela Convenção sobre Diversidade Biológica: "uma espécie introduzida que avança, sem assistência humana, e ameaça habitats naturais ou semi-naturais fora de seu território de origem" (Zalba e Ziller, 2005). Considerou-se como espécie-problema aquela com comportamento invasor, porém nativa. Neste trabalho, verificou-se a ocorrência de espécies invasoras nos trechos percorridos durante a amostragem da vegetação, de modo a se obter uma estimativa visual da frequência ou grau de infestação destas espécies.

\subsection{Zoneamento}

Segundo o Sistema Nacional de Unidades de Conservação da Natureza - SNUC, instituído pela Lei $\mathrm{n}^{\circ} 9.985 / 2000$, em seu artigo $2^{\circ}$ que considera o zoneamento como a definição de zonas em uma unidade de conservação com objetivos de manejo e normas específicos para que os objetivos da unidade possam ser alcançados de forma eficaz (Brasil, 2000a). Em um plano de manejo, o zoneamento é um instrumento de ordenamento territorial fundamental no planejamento da Unidade que permite, mediante a compartimentação da Unidade de Conservação, o direcionamento, a concentração de esforços e o estabelecimento das prioridades para as atividades de manejo (Galante et al., 2002).

O Roteiro Metodológico de Planejamento, publicado por Galante et al. (2002), estabelece as diretrizes para o zoneamento de Parques, Reservas Biológicas e Estações Ecológicas, e o zoneamento da Estação Ecológica de Avaré foi realizado conforme suas orientações: 
- Zona Primitiva - é uma área com pequena ou mínima intervenção humana. Contém espécies da flora e da fauna ou fenômenos naturais de grande valor científico. Seu objetivo é preservar o ambiente natural e ao mesmo tempo facilitar as atividades de pesquisa científica e educação ambiental.

- Zona de Recuperação - é uma área consideravelmente alterada pela ação antrópica ou natural. Trata-se de uma zona provisória. Seu objetivo é reverter processos de degradação e restaurar as características naturais. Após sua restauração será incorporada a uma outra zona. É permitida a educação ambiental.

- Zona de Uso Especial - é a zona na qual estão localizadas as áreas necessárias à administração, manutenção e serviços da Unidade de Conservação, abrangendo escritórios, alojamentos, habitações, oficinas, garagens e outros. Estas áreas geralmente não possuem características naturais relevantes.

- Zona de Uso Conflitante - são os espaços localizados em uma unidade de conservação que conflitam com os objetivos da Unidade de Conservação. São áreas ocupadas por estradas, linhas de transmissão, barragens, construções etc. Seu objetivo é minimizar a situação de conflito existente, estabelecendo procedimentos que reduzam os impactos à Unidade de Conservação.

- Zona de Uso Histórico-Cultural - é a zona em que se localizam objetos, construções ou estruturas que compõem o patrimônio histórico-cultural. Seu objetivo é a preservação do bem, possibilitando usos voltados à pesquisa e educação.

\section{RESULTADOS E DISCUSSÃO}

\subsection{Dados Secundários}

Não foram encontrados estudos em nível da comunidade vegetal realizados na EEcA ou no Horto Florestal Andrada e Silva. O único levantamento realizado foi o da proposta de criação da EEcA (Arzolla e Vilela, 2010), cujos registros foram considerados como dados primários.

A ausência de estudos sobre a vegetação na EEcA indica uma lacuna nessa área de conhecimento. Estudos florísticos e fitossociológicos que contemplem as diferentes formações e fitofisionomias existentes são prioritários para o conhecimento da Unidade.

Apenas o Herbário Dom Bento José Pickel do Instituto Florestal do estado de São Paulo (SPSF) apresentou informações sobre a composição florística da EEcA com apenas três registros. Os demais registros, encontrados no Species Link, correspondem a dados que foram considerados primários, pois foram obtidos nas campanhas de campo. Esses registros, incorporados à coleção do herbário SPSF, constavam no Species Link devido à constante atualização da coleção do herbário na rede.

As três espécies registradas na EEcA a partir dos dados secundários estão distribuídas em três famílias: Orchidaceae (Campylocentrum sp.), Rubiaceae (Manettia cordifolia Mart.) e Sapotaceae (Pouteria ramiflora (Mart.) Radlk.). Os hábitos representados são, respectivamente, o epifítico, lianescente e o arbóreo.

\subsection{Dados Primários}

\subsubsection{Formações vegetais e fitofisionomias}

Parte da região Sudeste do Brasil é considerada área estacionalmente seca, pois apresenta período desfavorável ao crescimento vegetal de quatro a cinco meses ao ano. Nessa condição climática, convivem formações vegetais dos biomas Cerrado e Mata Atlântica. As formações de Cerrado são comuns nos interflúvios, sobre solos profundos distróficos ou álicos e em áreas sujeitas a incêndios. As formações de Mata Atlântica ocorrem nos flúvios ou interflúvios geralmente associadas a solos mesotróficos ou eutróficos com maior teor de argila e capacidade de retenção hídrica (Coutinho, 1978). 
Na EEcA, foram identificadas formações de Mata Atlântica (Floresta Estacional Semidecidual Montana e Aluvial) sobre solos mesotróficos e de Cerrado (Savana Florestada (ecotonal), Savana Arborizada e Savana Gramíneo-Lenhosa), nos solos distróficos (Figura 2, Tabela 1).

No interior da Estação Ecológica de Avaré, o Cerrado e a Floresta Estacional Semidecidual encontram-se atualmente em diferentes estádios de regeneração: inicial, médio a avançado apresentando fisionomias abertas a densas em função do tempo transcorrido desde o início do processo de ocupação, os desbastes e o corte raso dos eucaliptos.

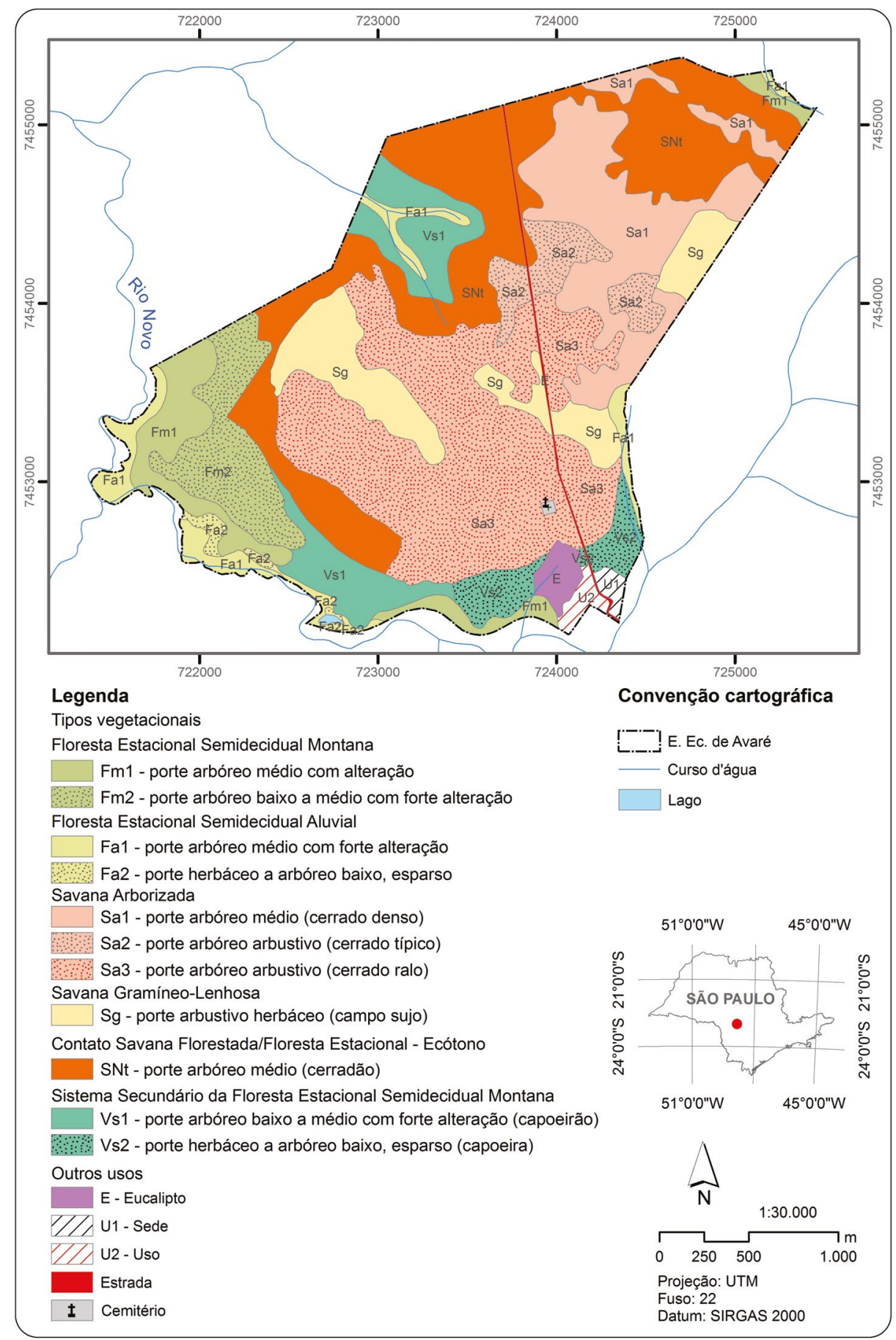

Figura 2. Formações vegetais e fisionomias encontradas na Estação Ecológica de Avaré.

Figure 2. Plant formations and physiognomies found in the Avaré Ecological Station. 
CIELO-FILHO, R. et al. Vegetação da Estação Ecológica de Avaré

Tabela 1. Uso e ocupação do solo na Estação Ecológica de Avaré.

Table 1. Land use in the Avaré Ecological Station.

\begin{tabular}{|c|c|c|}
\hline Formações vegetais e fisionomias & Área (ha) & $\%$ \\
\hline \multicolumn{3}{|l|}{ Floresta Estacional Semidecidual Montana - FESM } \\
\hline Fm1 - porte arbóreo médio com alteração & 38,43 & 5,33 \\
\hline Fm2 - porte arbóreo baixo a médio com forte alteração & 42,41 & 5,89 \\
\hline \multicolumn{3}{|l|}{ Floresta Estacional Semidecidual Aluvial - FESA } \\
\hline Fa1 - porte arbóreo médio com forte alteração & 27,96 & 3,88 \\
\hline $\mathrm{Fa} 2$ - porte herbáceo a arbóreo baixo, esparso & 4,1 & 0,57 \\
\hline \multicolumn{3}{|l|}{ Savana Arborizada - SA } \\
\hline Sa1 - porte arbóreo médio (cerrado denso) & 88,02 & 12,22 \\
\hline $\mathrm{Sa} 2$ - porte arbóreo arbustivo (cerrado típico) & 25,65 & 3,56 \\
\hline Sa3 - porte arbóreo arbustivo (cerrado ralo) & 186,17 & 25,84 \\
\hline \multicolumn{3}{|l|}{ Savana Gramíneo-Lenhosa - SGL } \\
\hline $\mathrm{Sg}$ - porte arbustivo herbáceo (campo sujo) & 59,74 & 8,29 \\
\hline \multicolumn{3}{|l|}{ Contato Savana Florestada/Floresta Estacional - Ecótono - E-SF/FES } \\
\hline $\mathrm{SNt}$ - porte arbóreo médio (cerradão) & 160,3 & 22,25 \\
\hline \multicolumn{3}{|l|}{ Sistema Secundário } \\
\hline Vs1 - porte arbóreo baixo a médio com forte alteração (capoeirão) & 48,96 & 6,80 \\
\hline Vs2 - porte herbáceo a arbóreo baixo, esparso (capoeira) & 20,51 & 2,85 \\
\hline \multicolumn{3}{|l|}{ Outros usos } \\
\hline E - Eucalipto & 7,27 & 1,01 \\
\hline Estrada & 2,64 & 0,37 \\
\hline U1 - Sede & 2,88 & 0,40 \\
\hline U2 - Uso & 4,32 & 0,60 \\
\hline Cemitério & 0,49 & 0,07 \\
\hline Lago & 0,56 & 0,08 \\
\hline TOTAL & 720,4 & 100 \\
\hline
\end{tabular}

\subsubsection{Floresta Estacional Semidecidual (Mata Atlântica)}

Segundo Leitão-Filho (1982), as Florestas Estacionais Semideciduais (Matas de Planalto) ocuparam uma área bastante expressiva das regiões Sul e Sudeste do Brasil, ao longo dos estados de São Paulo, parte do Paraná, parte de Minas Gerais, parte do Mato Grosso e Goiás e, em menor área, os estados do Rio de Janeiro e Espírito Santo. Refere ainda que as Florestas Estacionais ocorrem em áreas de clima e solo variados, com uma característica climática constante, invernos secos e/ou mais frios e verões úmidos e quentes. Esse conceito ecológico da Floresta Estacional Semidecidual é compartilhado por Veloso e Góes-Filho (1982). Leitão-Filho (1982) refere ainda que se trata de formação descontínua e, em alguns trechos, entremeadas por cerradões e cerrados, campos rupestres e matas ciliares. 
A Floresta Estacional está sujeita a um período de quatro a seis meses secos por ano ou sem um período seco, mas com três meses de seca fisiológica com temperatura média abaixo de $15{ }^{\circ} \mathrm{C}$ (IBGE, 2012). A caducifolia foi um dos critérios utilizados para a elaboração do atual sistema fitogeográfico brasileiro (IBGE, 2012). Nesse sistema, as florestas estacionais seriam semideciduais ou deciduais, sendo a queda foliar ocasionada por um longo período de estiagem acentuada para o clima tropical (médias de $22{ }^{\circ} \mathrm{C}$, quatro a seis meses secos) ou por um frio intenso (seca fisiológica) para o clima subtropical (médias de $18^{\circ} \mathrm{C}$ com pelo menos três meses com temperaturas de inverno inferiores a $15{ }^{\circ} \mathrm{C}$ ). Quanto à Floresta Estacional Semidecidual, a percentagem das árvores caducifólias no conjunto florestal, e não das espécies que perdem as folhas individualmente, situa-se entre 20 e $50 \%$ e, para a Floresta Estacional Decidual, o percentual deve ser de $50 \%$ ou mais. Na EEcA, a perda foliar está entre 20 e 50\%, o que a enquadra como Floresta Estacional Semidecidual.

A área remanescente desse tipo florestal no Estado de São Paulo está por volta de 5\% do que se estimou existir no século XIX. Nessa época, a maior intensidade de desmatamento desse tipo florestal deu-se devido ao cultivo de café e cana-de-açúcar, e a consequente ocupação humana e seus reflexos. "Esta formação arbórea é, talvez, a que maior devastação já sofreu, pois recobria, de início, a área em que a ocupação humana se fez sentir mais intensamente" (Romariz, 1996).

Parte da Floresta Estacional Semidecidual presente na EEcA é Montana, pois ocorre em altitudes acima de $500 \mathrm{~m}$, entre as latitudes $16^{\circ}$ e $24^{\circ}$ Sul (IBGE, 2012). Ainda, às margens do rio Novo e do córrego da Canela, nota-se a presença da Floresta Estacional Semidecidual Aluvial. Conforme já mencionado, a Floresta Estacional Semidecidual Montana da EEcA, muito provavelmente também foi alvo de desmatamento para o plantio de eucalipto. Isso, associado a eventos de incêndio e outras ações no passado remoto e recente, resultou no estado atual da cobertura vegetal dessa formação, parte dela fortemente alterada e em processo de transformação (Figura 3), embora em outros trechos a vegetação esteja em bom estado de conservação (Figura 4).

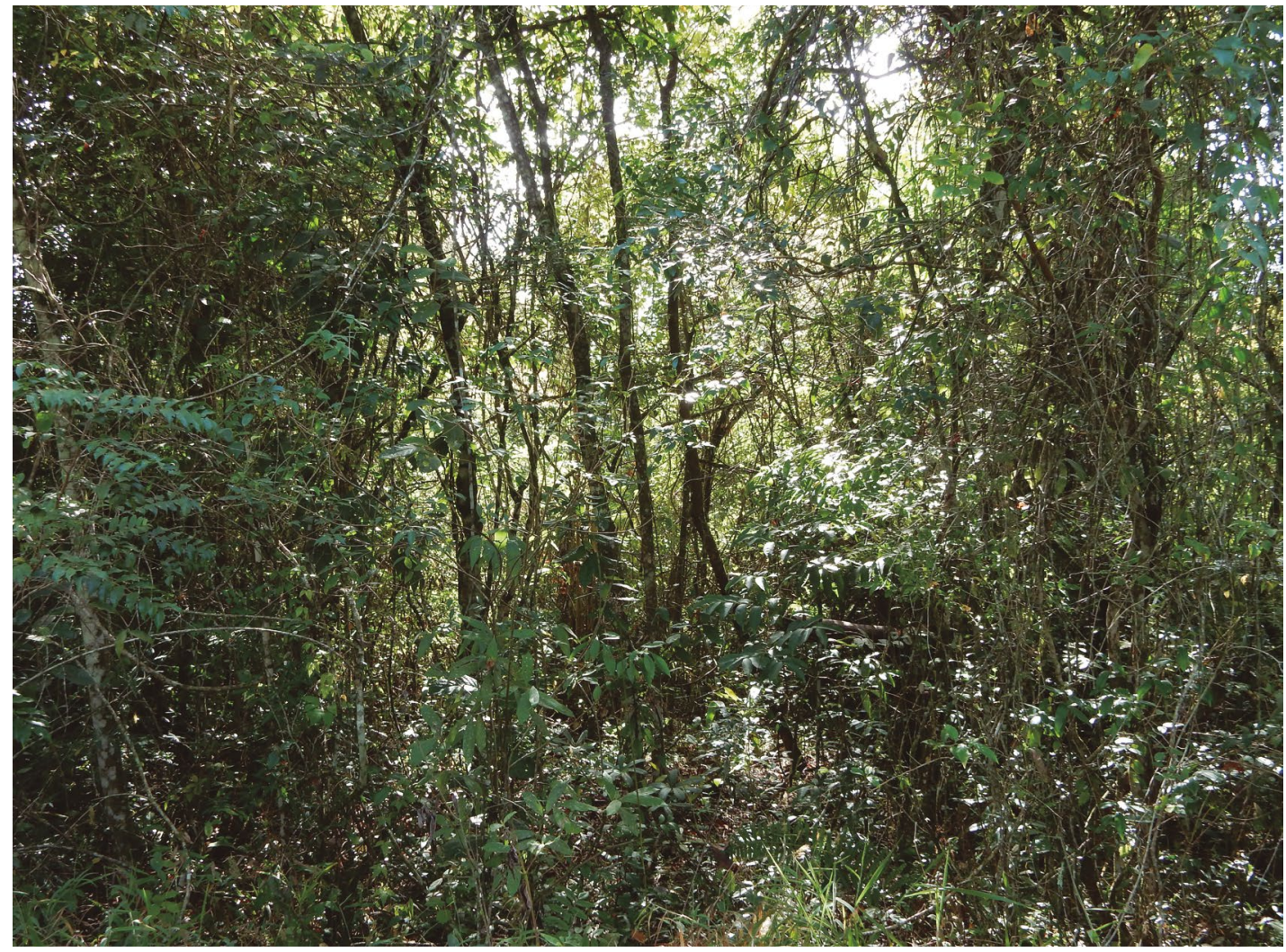

Figura 3. Trecho de Floresta Estacional Semidecidual Montana fortemente alterada na Estação Ecológica de Avaré - SP. (Foto: F.S.P. Vilela).

Figure 3. Stretch of Montane Semideciduous Seasonal Forest strongly altered in the Avaré Ecological Station - SP. (Photo: F.S.P. Vilela). 


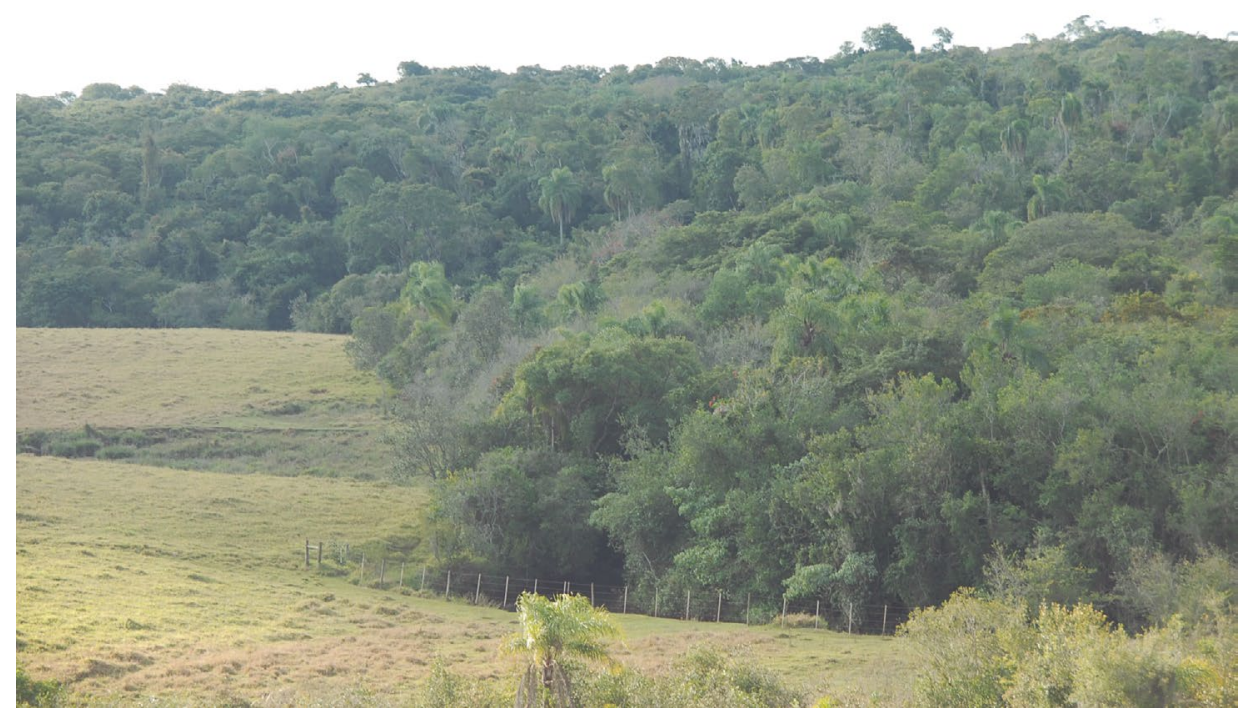

Figura 4. Vista geral do trecho mais conservado de Floresta Estacional Semidecidual Montana na região sudoeste da Estação Ecológica de Avaré - SP. (Foto: J.B. Baitello).

Figure 4. Overview of the most conserved stretch of the Montane Semideciduous Seasonal Forest in the Avaré Ecological Station - SP. (Photo: J.B. Baitello).

De acordo com IBGE (2012), a Floresta Estacional Semidecidual Aluvial sempre está associada ao ambiente fluvial, seja em áreas de nascentes ou várzeas de rios e córregos. No entanto, essa floresta se diferencia das demais formações ribeirinhas por ocorrer sobre solos hidromórficos e permanentemente inundados, em relevo de morrotes e canais superficiais de pequena dimensão. Ocorre também sobre solos aluvionais com inundação temporária, caso da Estação Ecológica de Avaré, especialmente em trechos das várzeas do rio Novo e do córrego da Canela.

Em função da restrição ambiental causada pela elevada saturação hídrica, poucas espécies arbóreas conseguem se estabelecer na Floresta Estacional Semidecidual Aluvial, mas estas são peculiares a esta formação (Ivanauskas et al., 1997; Toniato et al., 1998). Uma das espécies mais típicas nessa condição é Magnolia ovata, o baguaçu ou pinha-do-brejo, encontrada na grande maioria dessas florestas aluviais do Estado de São Paulo. Outras espécies da Floresta Estacional Semidecidual suportam as condições citadas e, comumente, também ocorrem nesse ambiente, tais como: Vochysia tucanorum, Siparuna brasiliensis, Nectandra lanceolata, Dahlstedtia muehlbergiana, Parapiptadenia rigida, Syagrus romanzzoffiana, Hedyosmum brasiliense, entre outras.

\subsubsection{Cerrado}

Os cerrados do Sul e Sudeste (SP, PR e sul de MG) constituem um padrão fitogeográfico distinto, correspondendo a 2,5\% da grande área ocupada pelo bioma no Brasil (Ratter et al., 2003). Trata-se da região com o clima mais úmido (precipitação média anual em torno de $1.450 \mathrm{~mm}$ ) e frio (temperatura média anual entre 20 e $24{ }^{\circ} \mathrm{C}$ ) dentro do bioma Cerrado, com ocorrência de geadas esporádicas (Brando e Durigan, 2004).

As áreas atuais de Cerrado no Estado de São Paulo ocorrem especialmente na Depressão Periférica e no Planalto Ocidental Paulista. Algumas manchas expressivas estão localizadas no Vale do Paraíba e no Planalto Atlântico em pleno domínio da Floresta Ombrófila Densa. Os remanescentes de Cerrado, no Estado, dividem-se em dois grandes grupos, distinguindo-se aqueles constituídos por Cerradão, mais a oeste, dos que apresentam fisionomias mais abertas, mais a leste (Castro e Martins, 1999; Durigan et al., 2003; Durigan, 2006). 
Segundo estimativa baseada em mapa da reconstituição da cobertura vegetal natural do Estado de São Paulo (Victor et al., 2005), o Cerrado ocupava cerca de 3.500 .000 ha (14\% da sua superfície) por volta de 1800, quando o território paulista contava com todos os tipos de vegetação praticamente intactos. Atualmente, os remanescentes de Cerrado no Estado somam cerca de $2.000 \mathrm{~km}^{2}$, com os milhares de fragmentos bastante dispersos. Apesar da área acima representar pouco menos que $1 \%$ da superfície do Estado, os remanescentes do Cerrado paulista preservam amostras significativas da flora do bioma, contendo cerca de $40 \%$ das espécies arbóreas amostradas por Ratter et al. (2003) em todo o país (Durigan et al., 2004; Durigan, 2006; Baitello et al., 2013). As peculiaridades climáticas e a proximidade com a Mata Atlântica fazem com que abriguem um número considerável de espécies exclusivas. Entre os fragmentos com maior riqueza de espécies vegetais no país, vários deles estão localizados em São Paulo, de modo que especialistas consideram que existem supercentros de biodiversidade no Estado (Castro e Martins, 1999).

Analisando-se a rede existente de unidades de conservação no Estado de São Paulo, do ponto de vista da representatividade dos diferentes tipos de vegetação, constata-se que apenas $0,5 \%$ da área original coberta por vegetação de Cerrado e zonas de tensão ecológica encontra-se protegidos, porção essa menor que a representatividade da Floresta Estacional Semidecidual (1\%) e muito inferior à da Floresta Ombrófila e formações costeiras, com 8,5\% protegidos em unidades de conservação, demonstrando evidente desequilíbrio (Durigan et al., 2007).

O Cerrado foi subdividido em IBGE (2012) em quatro subgrupos de formação: Savana Florestada (Cerradão), Savana Arborizada (Campo cerrado e Cerrado stricto sensu), Savana Gramíneo-Lenhosa (Campo limpo e Campo sujo) e Savana Parque (Parque de Cerrado). As três primeiras formações ocorrem na EEcA e diferem entre si pela cobertura dos estratos arbóreo e herbáceo.

A Savana Florestada (Cerradão) caracteriza-se pelo predomínio das árvores tortuosas com folhas coriáceas e órgãos de reserva subterrâneos conhecidos como xilopódios (IBGE, 2012). As árvores são microfanerófitos (5 a $20 \mathrm{~m}$ de altura) e nanofanerófitos $(0,25$ a $5 \mathrm{~m}$ de altura) com casca esfoliante corticosa ou profundamente fissurada. Ocorre especialmente em áreas areníticas lixiviadas com solos profundos, em clima tropical estacional.

A ocorrência da Savana Florestada na EEcA não está claramente individualizada, pois devido ao seu histórico, como já referimos, de extração da vegetação primitiva para o plantio de eucalipto, antes da década de 1960, em alguns trechos essa formação mescla suas espécies com as da Floresta Estacional Semidecidual, formando um rico ecótono florestal em franco processo de transformação.

$\mathrm{Na}$ EEcA, o ecótono Savana Florestada/Floresta Estacional Semidecidual recobre 160,3 ha (Figura 2, Tabela 1). Em geral o porte da vegetação é arbóreo médio, com altura e diâmetro médios aproximados de $7 \mathrm{~m}$ e $13 \mathrm{~cm}$ (Figura 5), respectivamente. As espécies dominantes são a copaíba-Copaifera langsdorffii, a maçaranduba - Persea willdenovii, a canela-do-cerrado - Ocotea corymbosa, o angico-do-cerrado Anadenanthera peregrina var. falcata, o salta-martim - Strychnos brasiliensis, a carne-de-vaca - Roupala montana, o cambuí - Myrcia multiflora e o capororocão - Myrsine umbellata.

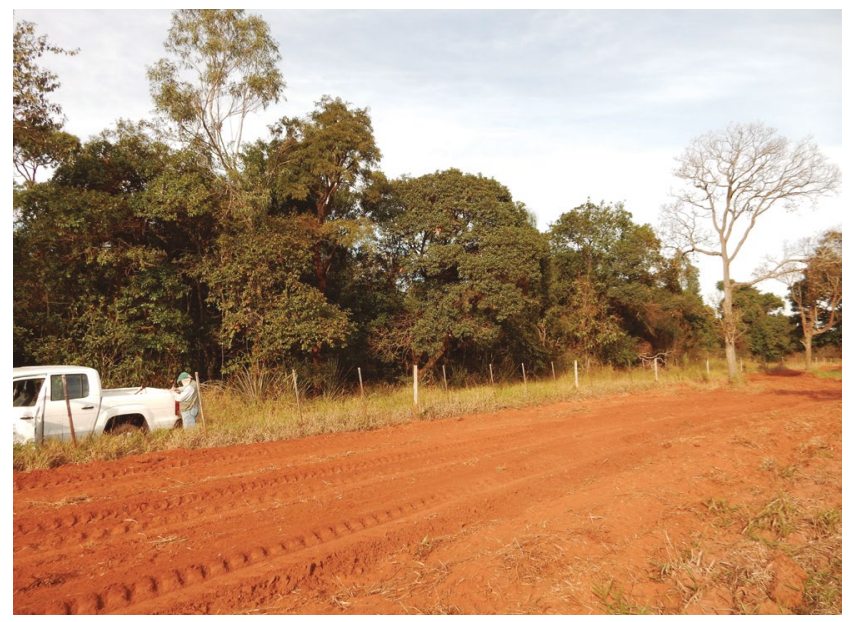

Figura 5. Vista geral do ecótono Savana Florestada/Floresta Estacional Semidecidual na Estação Ecológica de Avaré - SP. (Foto: F.S.P. Vilela).

Figure 5. Overview of the ecotone Forested Savana/Semideciduous Seasonal Forest in the Avaré Ecological Station - SP. (Photo: F.S.P. Vilela). 
A Savana Arborizada (Campo cerrado e Cerrado stricto sensu) apresenta três estratos bem definidos: o arbóreo, que é aberto e mais ou menos contínuo; o arbustivo-subarbustivo, que se mostra de aberto a denso e de composição florística muito variável, e o estrato herbáceo, constituído principalmente por gramíneas (Brandão et al., 1993).

As árvores são baixas, inclinadas, tortuosas, com ramificações irregulares e retorcidas e geralmente com evidências de queimadas. Os arbustos e subarbustos encontram-se espalhados, com algumas espécies apresentando órgãos subterrâneos perenes (xilopódios), que permitem a rebrota após a queima ou corte. A densidade arbórea varia de acordo com as condições edáficas (profundidade, $\mathrm{pH}$, saturação por bases e por alumínio, disponibilidade hídrica), com a frequência de queimadas e em função de ações antrópicas.

$\mathrm{Na}$ EEcA foi constatada a presença de três subtipos da Savana Arborizada denominados Cerrado denso - semelhante ao Cerrado sensu stricto ou à Savana Arborizada com maior densidade de elementos arbóreos (Figura 6), Cerrado ralo - semelhante ao Campo cerrado ou à Savana Arborizada com menor densidade de elementos arbóreos (Figura 7) e um subtipo intermediário denominado Cerrado típico (Figura 8), conforme nomenclatura proposta por Ribeiro e Walter (2008).

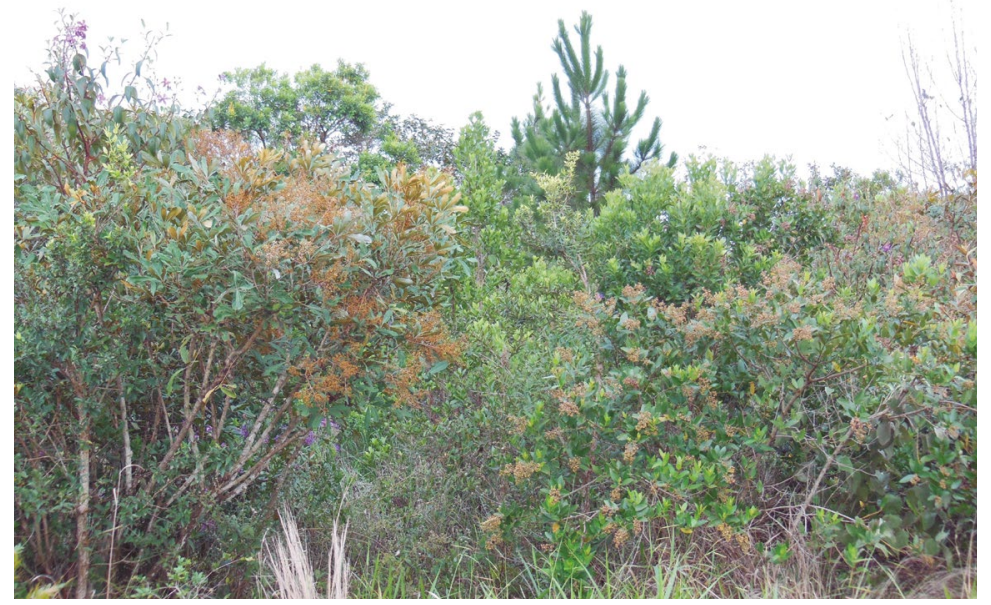

Figura 6. Trecho de Savana Arborizada mais densa ou Cerrado denso com invasão de Pinus sp. na Estação Ecológica de Avaré - SP. (Foto: J.B. Baitello).

Figure 6. Stretch of denser Arboreal Savanna or Cerrado denso with invasion of Pinus sp. in the Avare Ecological Station - SP. (Photo: J.B. Baitello).

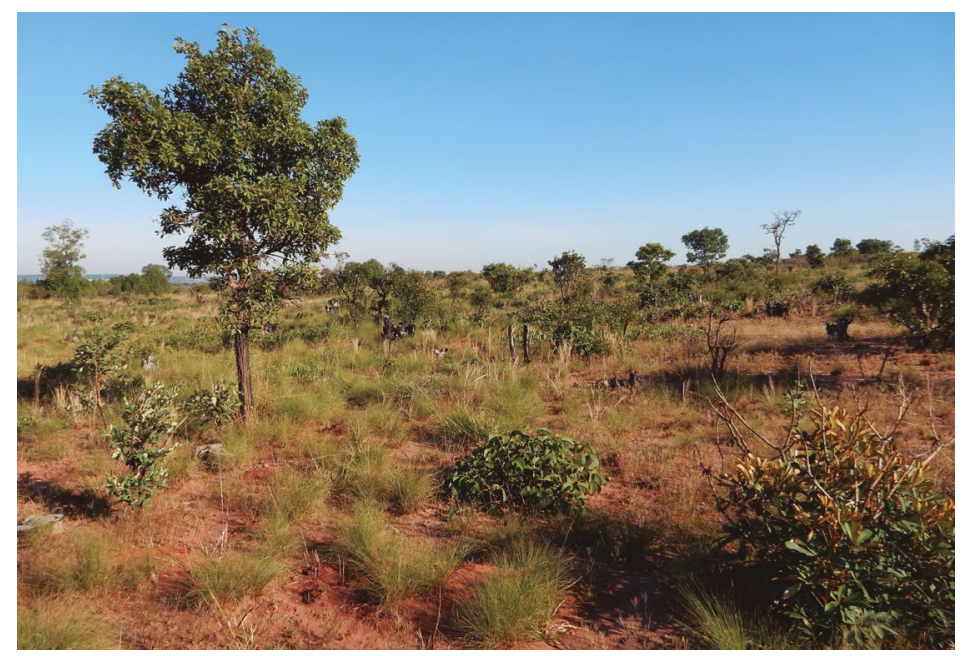

Figura 7. Vista geral de trecho com Savana Arborizada (Cerrado ralo) na Estação Ecológica de Avaré - SP. (Foto: F.S.P. Vilela). Figure 7. Overview of stretch of Arboreal Savanna (Cerrado ralo) in the Avaré Ecological Station - SP. (Photo: F.S.P. Vilela). 


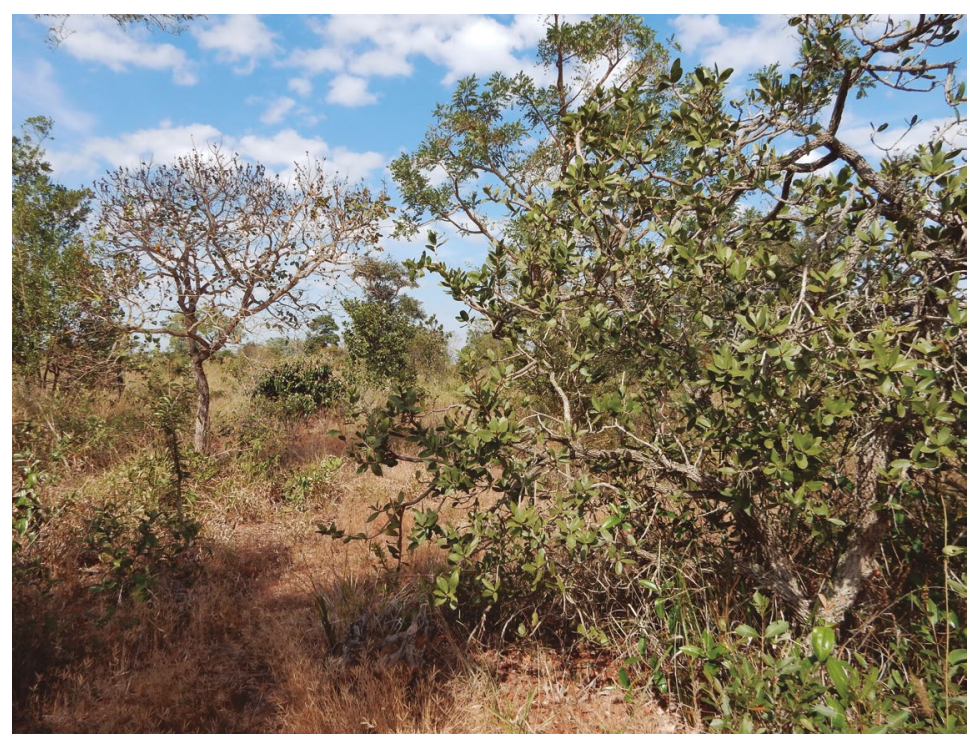

Figura 8. Vista geral de trecho com Savana Arborizada (Cerrado típico) na Estação Ecológica de Avaré - SP. (Foto: F.S.P. Vilela). Figure 8. Overview of stretch of Arboreal Savanna (Cerrado típico) in the Avaré Ecological Station - SP. (Photo: F.S.P. Vilela).

A composição de espécies lenhosas nesses três subtipos é semelhante, destacando-se: o angico-do-cerrado Anadenanthera peregrina var. falcata, o peito-de-pombo - Tapirira guianensis, o capororocão - Myrsine umbellata, a canela-do-cerrado - Ocotea corymbosa, o barbatimão - Stryphnodendron adstringens e S. rotundifolium, o amendoim-do-campo - Platypodium elegans, a mandioqueira - Schefflera vinosa, entre outras.

A Savana Gramíneo-Lenhosa é uma fitofisionomia campestre com composição florística bastante diversificada, sendo caracterizada por um estrato herbáceo entremeado por plantas lenhosas em densidade variável (IBGE, 2012). Ribeiro e Walter (2008) consideram a Savana Gramíneo-Lenhosa englobando três tipos fitofisionômicos campestres: o Campo sujo, o Campo rupestre e o Campo limpo. Apenas o Campo sujo foi detectado na EEcA caracterizando-se pela presença marcante de arbustos e subarbustos em meio ao estrato herbáceo, este constituído especialmente por Poaceae (Figura 9). Os estratos subarbustivo e arbustivo são dominados por espécies de Melastomataceae, Asteraceae, Lamiaceae, Fabaceae, Rubiaceae e Malvaceae, entre outras.

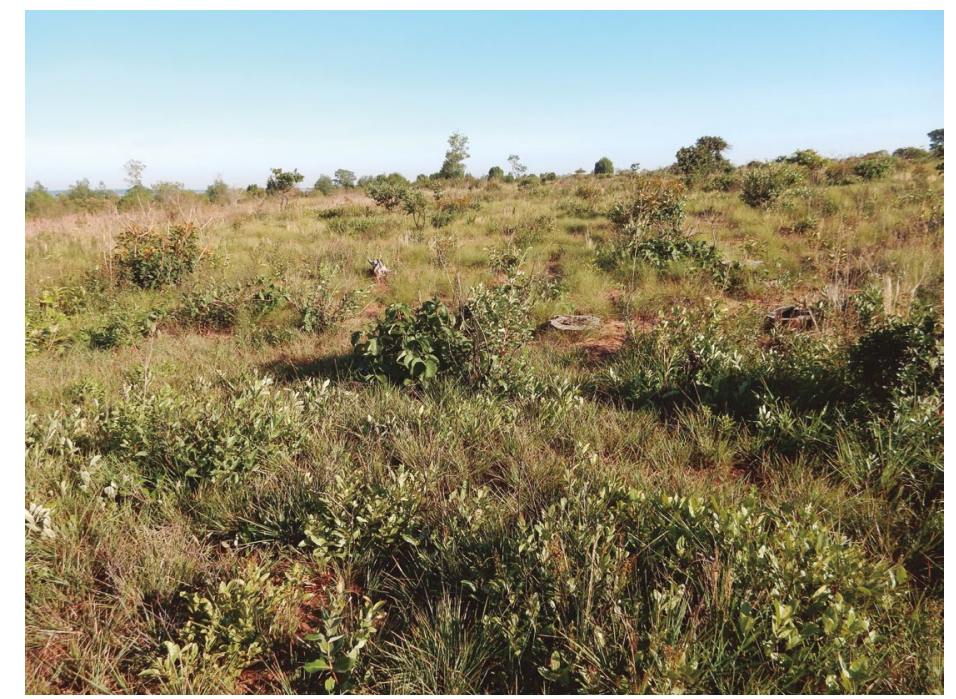

Figura 9. Trecho com Savana Gramíneo-Lenhosa (Campo sujo) na Estação Ecológica de Avaré - SP. (Foto: F.S.P. Vilela). Figure 9. Stretch with Wood-Grassland Savanna (Campo sujo) in the Avaré Ecological Station - SP. (Photo: F.S.P. Vilela). 


\subsubsection{Composição florística das fisionomias amostradas}

$\mathrm{Na}$ EEcA foram identificadas cinco formações vegetais: a Floresta Estacional Semidecidual Montana - FESM; a Floresta Estacional Semidecidual Aluvial - FESA; a Savana Arborizada - SA; a Savana Gramíneo-Lenhosa - SGL e o Ecótono Savana Florestada/Floresta Estacional Semidecidual - E-SF/FES.

Nas formações de Mata Atlântica (FESM e FESA) foram encontradas 39 famílias, 73 gêneros e 93 espécies, sendo que $61(66 \%)$ espécies foram registradas exclusivamente nessas formações. As famílias botânicas mais representativas em número de espécies foram: Fabaceae (15 espécies), Lauraceae (8), Rubiaceae (7), Euphorbiaceae, Meliaceae e Myrtaceae (4); juntas somaram 42 espécies, ou seja, $45 \%$ do conjunto de espécies nas referidas formações. Os gêneros mais ricos foram Myrsine, Nectandra e Ocotea, com três espécies cada.

Para efeitos de análise da composição florística, a formação ecotonal E-SF/FES foi considerada em conjunto com as formações de Cerrado (SA e SGL). Nessas três formações, foram registradas 204 espécies distribuídas em 46 famílias e 135 gêneros. Desse conjunto florístico, 172 espécies (84\%) não foram compartilhadas com as formações de Mata Atlântica FESM e FESA. As famílias mais representativas em número de espécies foram: Asteraceae (27 espécies), Fabaceae (24), Myrtaceae (18), Rubiaceae (13) e Poaceae (10), totalizando 92 espécies (45\%). Dentre os gêneros mais representativos destacaram-se Myrcia (7 espécies), Miconia (6) e Ocotea (5).

As famílias botânicas de maior riqueza no cerrado da EEcA estão citadas entre as principais famílias ocorrentes em áreas de Cerrado no Estado de São Paulo (Cavassan, 2002) e no Brasil (Mendonça et al., 2008), cabendo destaque especial para Fabaceae, a de maior riqueza em grande parte dos estudos no bioma Cerrado (Mendonça et al., 2008). Essas famílias também se destacaram na flora dos cerrados das Estações Ecológicas de Assis (Durigan et al., 1999; Rossato et al., 2008), Itapeva (Cielo-Filho et al., 2012) e Santa Bárbara (Meira Neto et al., 2007).

Nas formações de Mata Atlântica (FESM e FESA), o hábito arbóreo foi representado por 87 espécies, predominando, em número de espécies, sobre o conjunto dos hábitos não arbóreos. Contribuiu para esse predomínio um viés da amostragem que privilegiou as árvores. No caso das formações de Cerrado (SA, SGL) e ecotonal (E-SF/FES), todos os hábitos foram igualmente enfatizados durante a amostragem e a distribuição de espécies entre os hábitos de crescimento foi mais uniforme. Assim, os números de espécies arbóreas (108) e não arbóreas (96) foram parecidos. A razão entre o número de espécies não arbóreas e arbóreas foi de $96 / 108=0,89$ e indica que a flora da EEcA ainda é subamostrada. A representatividade relativamente elevada das fisionomias campestres e savânicas na EEcA sugere que essa razão provavelmente aumentará à medida em que a composição florística da Unidade se tornar mais conhecida. O componente não arbóreo é entre 3 e 4,5 vezes mais rico que o arbóreo na flora do bioma Cerrado (Filgueiras, 2002), o que aumenta a significância de unidades de conservação que abrigam fisionomias vegetais abertas, onde o componente não arbóreo está bem representado, tais como as fisionomias campestres e savânicas.

\subsection{Síntese da Composição Florística da Estação Ecológica de Avaré}

\subsubsection{Riqueza de espécies vegetais}

$\mathrm{Na}$ área da EEcA, considerando dados primários e secundários, foram registradas 265 espécies distribuídas em 174 gêneros e 66 famílias de plantas vasculares (Tabela 2). Grande parte da riqueza de espécies na EEcA deve-se às famílias Fabaceae (35 espécies), Asteraceae (28), Myrtaceae (22), Rubiaceae (20), Lauraceae (11), Poaceae (10), Malvaceae (9), Bignoniaceae e Melastomataceae (8), Euphorbiaceae (7), Lamiaceae e Celastraceae (6), representando 64\% das espécies registradas. Cerca de $42 \%$ das famílias (28) estiveram representadas por apenas uma espécie. Os gêneros mais ricos foram Myrcia e Miconia (7 espécies), Ocotea (6), Chromolaena, Eugenia, Myrsine (4), Solanum, Palicourea, Piptocarpha, Pterocaulon, Jacaranda, Maytenus, Erythroxylum, Chamaecrista, Mimosa, Nectandra, Sida, Campomanesia, Chomelia e Cordiera (3 espécies cada). 
Tabela 2. Espécies vasculares registradas na Estação Ecológica de Avaré - SP. SPSF, número de tombo em herbário. FESM, Floresta Estacional Semidecidual Montana. FESA, Floresta Estacional Semidecidual Aluvial. SA, Savana Arborizada. SGL, Savana Gramíneo-Lenhosa. E-SF/FES, Ecótono Savana Florestada/Floresta Estacional Semidecidual. Asterisco, espécie exótica. Av, árvore. Ab, arbusto. Sb, subarbusto. Hr, herbácea. La, liana.

Table 2. Vascular species recorded in the Avaré Ecological Station - SP. SPSF, herbarium record number. FESM, Montane Semideciduous Seasonal Forest, FESA, Aluvial Semideciduous Seasonal Forest. SA, Arboreal Savanna. SGL, Wood-Grassland Savanna. E-SF/FES, ecotone Forested Savana/Semideciduous Seasonal Forest. Asteristic, exotic species. Av, tree. Ab, shrub. Sb, sub-shrub. Hr, herbaceous. La, liana.

\begin{tabular}{|c|c|c|c|c|}
\hline FAMÍLIA/Espécie & Hábito & SPSF & Fisionomia & Nome Popular \\
\hline \multicolumn{5}{|l|}{ AMARANTHACEAE } \\
\hline Alternanthera sp. & $\mathrm{Hr}$ & 48841 & SA, SGL & periquito \\
\hline \multicolumn{5}{|l|}{ ANACARDIACEAE } \\
\hline Lithrea molleoides (Vell.) Engl. & $\mathrm{Av}$ & 44017 & FESM & aroeira-brava \\
\hline Schinus terebinthifolius Raddi & Av & Estéril & FESM & aroeira-pimenteira \\
\hline Tapirira guianensis Aubl. & Av & 43999 & FESM & peito-de-pombo \\
\hline \multicolumn{5}{|l|}{ ANNONACEAE } \\
\hline Annona coriacea Mart. & Av & 44003 & SA & araticum-do-campo \\
\hline Annona emarginata (Schltdl.) H.Rainer & Av & Estéril & FESM, SA, SGL & araticum \\
\hline Duguetia furfuracea (A.St.-Hil.) Saff. & $\mathrm{Ab}$ & 48742 & SGL & marolinho-do-cerrado \\
\hline Guatteria australis A.St.-Hil. & Av & Estéril & FESM & pindaíba \\
\hline \multicolumn{5}{|l|}{ APOCYNACEAE } \\
\hline Aspidosperma cylindrocarpon Müll. Arg. & Av & Estéril & FESM & peroba-poca \\
\hline Tabernaemontana catharinensis A.DC. & Av & 43941 & FESM & leiteiro \\
\hline \multicolumn{5}{|l|}{ AQUIFOLIACEAE } \\
\hline Ilex paraguariensis A.St.-Hil. & Av & 43942,48748 & $\begin{array}{l}\text { E-SF/FES, } \\
\text { FESM, FESA }\end{array}$ & erva-mate \\
\hline \multicolumn{5}{|l|}{ ARALIACEAE } \\
\hline \multicolumn{5}{|l|}{ ARECACEAE } \\
\hline Allagoptera campestris (Mart.) Kuntze & Av & 48810 & SGL & buri-do-campo \\
\hline Syagrus romanzoffiana (Cham.) Glassman & Av & Estéril & $\begin{array}{l}\text { E-SF/FES, } \\
\text { FESM, FESA }\end{array}$ & jerivá \\
\hline \multicolumn{5}{|l|}{ ASPARAGACEAE } \\
\hline Cordyline spectabilis Kunth \& Bouché & $\mathrm{Ab}$ & Estéril & $\begin{array}{l}\text { E-SF/FES, } \\
\text { FESM, FESA }\end{array}$ & guarânia \\
\hline \multicolumn{5}{|l|}{ ASTERACEAE } \\
\hline Acanthospermum australe (Loefl.) Kuntze & $\mathrm{Hr}$ & 48709 & SA, SGL & carrapicho-rasteiro \\
\hline Achyrocline satureioides (Lam.) DC. & $\mathrm{Hr}$ & 48711 & SGL & macela \\
\hline $\begin{array}{l}\text { Austroeupatorium silphiifolium (Mart.) R.M.King } \\
\text { \& H.Rob. }\end{array}$ & $\mathrm{Ab}$ & 48598,48610 & SA, SGL & erva-de-embira \\
\hline Baccharis dracunculifolia DC. & $\mathrm{Ab}$ & 48601,48605 & SGL & alecrim-do-campo- \\
\hline Bidens cf. gardneri Baker & $\mathrm{Sb}$ & 48843 & SA, SGL & picão \\
\hline Chromolaena cf. squalida (DC.) R.M.King \& H.Rob. & $\mathrm{Ab}$ & 48609 & SA, SGL & erva-de-são-miguel \\
\hline Chromolaena laevigata (Lam.) R.M.King \& H.Rob. & $\mathrm{Ab}$ & 43928 & SGL & cambará-falso \\
\hline
\end{tabular}


continuação - Tabela 2

continuation - Table 2

\begin{tabular}{|c|c|c|c|c|}
\hline FAMÍLIA/Espécie & Hábito & SPSF & Fisionomia & Nome Popular \\
\hline $\begin{array}{l}\text { Chromolaena maximilianii (Schrad. } \\
\text { R.M.King \& H.Rob. }\end{array}$ & $\mathrm{Ab}$ & 48603 & SGL & mata-pasto \\
\hline Chromolaena pungens (Gardner) R.M.King \& H.Rob. & $\mathrm{Ab}$ & 48600 & SGL & \\
\hline Elephantopus cf. biflorus (Less.) Sch.Bip. & $\mathrm{Hr}$ & 48602 & SGL & capim-elefante \\
\hline Emilia fosbergii Nicolson & $\mathrm{Hr}$ & 48743 & SA, SGL & serralha-mirim \\
\hline Erechtites valerianifolius (Wolf) DC. & $\mathrm{Hr}$ & 48859 & SGL & caruru-amargoso \\
\hline Mikania cordifolia (L.f.) Willd. & $\mathrm{La}$ & 48596,48813 & SGL & cipó-cabeludo \\
\hline Moquiniastrum barrosoae (Cabrera) G. Sancho & $\mathrm{Ab}$ & 48794 & SGL & \\
\hline Moquiniastrum polymorphum (Less.) G. Sancho & $\mathrm{Av}, \mathrm{Ab}$ & estéril & E-SF/FES & cambará \\
\hline Moquiniastrum pulchrum (Cabrera) G. Sancho & $\mathrm{Ab}$ & 48604,48613 & SGL & \\
\hline Piptocarpha angustifolia Dusén ex Malme & $\mathrm{Av}, \mathrm{Ab}$ & 43996 & FESM & vassourão-branco \\
\hline Piptocarpha axillaris (Less.) Baker & $\mathrm{Av}$ & 43997 & SA & candeia \\
\hline Piptocarpha rotundifolia (Less.) Baker & $\mathrm{Av}, \mathrm{Ab}$ & 48771 & SA, SGL & candeia \\
\hline Praxelis clematidea (Griseb.) R.M.King \& H.Rob. & $\mathrm{Sb}$ & 48612 & SA, SGL & \\
\hline Pterocaulon alopecuroides (Lam.) DC. & $\mathrm{Sb}$ & 48806,48807 & SA, SGL & barbaço \\
\hline Pterocaulon lanatum Kuntze & $\mathrm{Sb}$ & 48611 & SA, SGL & verbasco \\
\hline Pterocaulon rugosum (Vahl) Malme & $\mathrm{Sb}$ & 48608 & SA, SGL & \\
\hline Vernonanthura divaricata (Spreng.) H.Rob. & $\mathrm{Av}, \mathrm{Ab}$ & 44013 & SGL & \\
\hline Vernonanthura phosphorica (Vell.) H.Rob. & $\mathrm{Ab}$ & Estéril & SA, SGL & \\
\hline Vernonanthura sp.1 & $\mathrm{Ab}$ & 48606 & SGL & \\
\hline Vernonanthura sp. 2 & $\mathrm{Ab}$ & 48599 & SGL & \\
\hline Vernonia sp. & $\mathrm{Ab}$ & 48833,48597 & SGL & \\
\hline \multicolumn{5}{|l|}{ BIGNONIACEAE } \\
\hline Amphilophium sp. & $\mathrm{La}$ & 48801 & SGL & \\
\hline Anemopaegma arvense (Vell.) Stellfeld ex de Souza & $\mathrm{Ab}$ & 43929,48719 & SGL & catuaba \\
\hline Cybistax antisyphilitica (Mart.) Mart. & $\mathrm{Av}$ & Estéril & SA & caroba-de-flor-verde \\
\hline Fridericia speciosa Mart. & $\mathrm{Ab}$ & 48747 & SGL & cipó-vermelho \\
\hline Handroanthus ochraceus (Cham.) Mattos & $\mathrm{Av}$ & Estéril & $\begin{array}{l}\text { FESM, FESA, } \\
\text { E-SF/FES }\end{array}$ & ipê-amarelo-do-cerrado \\
\hline Jacaranda caroba (Vell.) DC. & $\mathrm{Ab}$ & 48749 & SA, SGL & carobinha \\
\hline Jacaranda oxyphylla Cham. & $\mathrm{Av}, \mathrm{Ab}$ & Estéril & E-SF/FES & caroba-de-são-paulo \\
\hline Jacaranda rufa Silva Manso & $\mathrm{Ab}$ & 48825,48823 & SGL & caroba-do-campo \\
\hline \multicolumn{5}{|l|}{ BORAGINACEAE } \\
\hline Cordia sellowiana Cham. & $\mathrm{Av}$ & 48795 & $\begin{array}{l}\text { E-SF/FES, } \\
\text { FESM, FESA }\end{array}$ & chá-de-bugre \\
\hline $\begin{array}{l}\text { Cordia trichotoma (Vell.) Arráb. ex Steud. } \\
\text { BROMELIACEAE }\end{array}$ & $\mathrm{Av}$ & Estéril & FESM, FESA, SA & louro-pardo \\
\hline Aechmea bromeliifolia (Rudge) Baker & $\mathrm{Hr}$ & Estéril & E-SF/FES & bromélia \\
\hline Ananas ananassoides (Baker) L.B.Sm. & $\mathrm{Ab}$ & Estéril & SGL & abacaxi-do-cerrado \\
\hline Bromelia balansae $\mathrm{Mez}$ & $\mathrm{Hr}$ & Estéril & SGL & caraguatá \\
\hline
\end{tabular}


CIELO-FILHO, R. et al. Vegetação da Estação Ecológica de Avaré

continuação - Tabela 2

continuation - Table 2

\begin{tabular}{|c|c|c|c|c|}
\hline FAMÍLIA/Espécie & Hábito & SPSF & Fisionomia & Nome Popular \\
\hline \multicolumn{5}{|l|}{ CALOPHYLLACEAE } \\
\hline Kielmeyera coriacea Mart. \& Zucc. & Av & Estéril & SA & pau-santo \\
\hline $\begin{array}{l}\text { Kielmeyera variabilis Mart. \& Zucc. } \\
\text { CANNABACEAE }\end{array}$ & $\mathrm{Ab}$ & 48750 & SA, SGL & malva-de-campo \\
\hline Celtis iguanaea (Jacq.) Sarg. & $\mathrm{Av}, \mathrm{Ab}$ & Estéril & $\begin{array}{l}\text { FESM, FESA, } \\
\text { E-SF/FES }\end{array}$ & jameri \\
\hline Trema micrantha (L.) Blume & $\mathrm{Av}, \mathrm{Ab}$ & Estéril & SA, SGL & crindiúva \\
\hline \multicolumn{5}{|l|}{ CARYOCARACEAE } \\
\hline $\begin{array}{l}\text { Caryocar brasiliense Cambess. } \\
\text { CELASTRACEAE }\end{array}$ & $\mathrm{Av}, \mathrm{Ab}$ & 44012,48730 & SA, SGL & pequi \\
\hline Maytenus aquifolia Mart. & $\mathrm{Av}, \mathrm{Ab}$ & Estéril & SA & espinheira-santa \\
\hline Maytenus evonymoides Reissek & Av & Estéril & FESM & cafezinho \\
\hline Maytenus gonoclada Mart. & $\mathrm{Av}, \mathrm{Ab}$ & Estéril & FESM & cafezinho \\
\hline Maytenus sp. & Av & Estéril & SA, SGL & \\
\hline Peritassa campestris (Cambess.) A.C.Sm. & $\mathrm{Ab}$ & 43991, 48812 & SA, SGL & bacupari \\
\hline Plenckia populnea Reissek & Av & Estéril & FESM, SA & marmeleiro \\
\hline \multicolumn{5}{|l|}{ CHLORANTHACEAE } \\
\hline $\begin{array}{l}\text { Hedyosmum brasiliense Mart. ex Miq. } \\
\text { CHRYSOBALANACEAE }\end{array}$ & \multicolumn{3}{|c|}{ CHRYSOBALANACEAE } & chá-de-soldado \\
\hline Couepia grandiflora (Mart. \& Zucc.) Benth. & Av & Estéril & FESM & oiti-do-sertão \\
\hline \multicolumn{5}{|l|}{ CLETHRACEAE } \\
\hline $\begin{array}{l}\text { Clethra scabra Pers. } \\
\text { CLUSIACEAE }\end{array}$ & $\mathrm{Av}$ & 43943 & FESM & guaperê \\
\hline $\begin{array}{l}\text { Garcinia gardneriana (Planch. \& Triana) Zappi } \\
\text { COMBRETACEAE }\end{array}$ & $\mathrm{Av}, \mathrm{Ab}$ & Estéril & SA, SGL & bacupari \\
\hline $\begin{array}{l}\text { Terminalia argentea Mart. } \\
\text { COMMELINACEAE }\end{array}$ & $\mathrm{Av}$ & Estéril & FESM, FESA & capitão-do-campo \\
\hline $\begin{array}{l}\text { Commelina obliqua Vahl } \\
\text { CONNARACEAE }\end{array}$ & $\mathrm{Hr}$ & 48735 & SA, SGL & trapoeraba-azul \\
\hline $\begin{array}{l}\text { Rourea pseudospadicea G.Schellenb. } \\
\text { CONVOLVULACEAE }\end{array}$ & \multicolumn{3}{|c|}{ CONVOLVULACEAE } & \\
\hline $\begin{array}{l}\text { Merremia digitata (Spreng.) Hallier f. var. digitata } \\
\text { CUCURBITACEAE }\end{array}$ & $\mathrm{Hr}, \mathrm{La}$ & 48839 & SA, SGL & campainha \\
\hline Cayaponia espelina (Silva Manso) Cogn. & $\mathrm{La}$ & 48731,48804 & SA, SGL & espelina \\
\hline $\begin{array}{l}\text { Melothria campestris (Naudin) H.Schaefn. \& } \\
\text { S.S.Renner }\end{array}$ & $\mathrm{Hr}$ & 48753 & SA, SGL & melãozinho-do-cerrado \\
\hline \multicolumn{5}{|l|}{ CYPERACEAE } \\
\hline $\begin{array}{l}\text { Rhynchospora sp. } \\
\text { DENNSTAEDTIACEAE }\end{array}$ & $\mathrm{Hr}$ & 48842 & SGL & \\
\hline Pteridium arachnoideum (Kaulf.) Maxon & $\mathrm{Hr}$ & Estéril & SGL & $\begin{array}{r}\text { continua } \\
\text { be continued }\end{array}$ \\
\hline
\end{tabular}


continuação - Tabela 2

continuation - Table 2

\begin{tabular}{|c|c|c|c|c|}
\hline FAMÍLIA/Espécie & Hábito & SPSF & Fisionomia & Nome Popular \\
\hline \multicolumn{5}{|l|}{ DILLENIACEAE } \\
\hline Davilla rugosa Poir. & $\mathrm{La}$ & 48740 & SGL & cipó-caboclo \\
\hline \multicolumn{5}{|l|}{ ERYTHROXYLACEAE } \\
\hline Erythroxylum campestre A.St.-Hil. & $\mathrm{Ab}$ & 48744, 48746 & SGL & mercúrio-do-campo \\
\hline Erythroxylum deciduum A.St.-Hil. & $\mathrm{Ab}$ & Estéril & FESM & fruta-de-pomba \\
\hline Erythroxylum suberosum A.St.-Hil. & $\mathrm{Av}, \mathrm{Ab}$ & 48745 & SA, SGL & galinha-choca \\
\hline \multicolumn{5}{|l|}{ EUPHORBIACEAE } \\
\hline Alchornea glandulosa Poepp. \& Endl. & Av & Estéril & $\begin{array}{l}\text { E-SF/FES, } \\
\text { FESM, FESA }\end{array}$ & tapiá-guaçu \\
\hline Alchornea triplinervia (Spreng.) Müll.Arg. & Av & Estéril & $\begin{array}{l}\text { FESM, FESA, } \\
\text { SA }\end{array}$ & tapiá \\
\hline Croton floribundus Spreng. & Av & 44005 & $\begin{array}{l}\text { E-SF/FES, } \\
\text { FESM, FESA }\end{array}$ & capixingui \\
\hline Croton urucurana Baill. & Av & Estéril & $\begin{array}{l}\text { E-SF/FES, } \\
\text { FESM, FESA }\end{array}$ & sangra-d'água \\
\hline Gymnanthes klotzschiana Müll.Arg. & $\mathrm{Av}, \mathrm{Ab}$ & 43998 & FESA, SA, SGL & branquilho \\
\hline Maprounea guianensis Aubl. & $\mathrm{Av}$ & Estéril & SA & marmelinho-do-campo \\
\hline Microstachys daphnoides (Mart.) Müll.Arg. & $\mathrm{Ab}, \mathrm{La}$ & 48817,48818 & SGL & \\
\hline \multicolumn{5}{|l|}{ FABACEAE } \\
\hline Albizia niopoides (Benth.) Burkart & $\mathrm{Ab}$ & Estéril & $\begin{array}{l}\text { FESM, FESA, } \\
\text { E-SF/FES }\end{array}$ & farinha-seca \\
\hline Anadenanthera colubrina (Vell.) Brenan & Av & Estéril & FESM & angico-branco \\
\hline $\begin{array}{l}\text { Anadenanthera peregrina var. falcata (Benth.) } \\
\text { Altschul }\end{array}$ & Av & 44016 & $\begin{array}{l}\text { FESM, FESA, } \\
\text { E-SF/FES }\end{array}$ & angico-do-cerrado \\
\hline Andira humilis Mart ex Benth. & $\mathrm{Ab}$ & 44010,48824 & SGL & angelim-rasteiro \\
\hline Bauhinia longifolia (Bong.) Steud. & $\mathrm{Av}, \mathrm{Ab}$ & 43944 & FESM & pata-de-vaca \\
\hline Bauhinia rufa (Bong.) Steud. & $\mathrm{Av}, \mathrm{Ab}$ & $\begin{array}{l}43930,48723 \\
48724\end{array}$ & SA, SGL & pata-de-vaca \\
\hline $\begin{array}{l}\text { Chamaecrista cathartica (Mart.) H.S.Irwin \& } \\
\text { Barneby }\end{array}$ & $\mathrm{Ab}$ & Estéril & SGL & sene-do-campo \\
\hline $\begin{array}{l}\text { Chamaecrista desvauxii (Collad.) Killip var. } \\
\text { desvauxii }\end{array}$ & $\mathrm{Ab}, \mathrm{Sb}$ & 48732 & SGL & sene \\
\hline $\begin{array}{l}\text { Chamaecrista desvauxii var. latistipula (Benth.) } \\
\text { G.P.Lewis }\end{array}$ & $\mathrm{Ab}, \mathrm{Sb}$ & 48733 & SA, SGL & sene \\
\hline Clitoria densiflora (Benth.) Benth. & $\mathrm{Ab}, \mathrm{Sb}$ & 48734 & SA, SGL & feijão-do-campo \\
\hline Copaifera langsdorffii Desf. & Av & Estéril & E-SF/FES, SA & óleo-de-copaíba \\
\hline Crotalaria micans Link & $\mathrm{Ab}$ & 48736 & SA, SGL & guizo-de-cascavél \\
\hline $\begin{array}{l}\text { Dahlstedtia floribunda (Vogel) M.J.Silva \& } \\
\text { A.M.G.Azevedo }\end{array}$ & Av & 43945 & FESM, FESA & embira-de-sapo \\
\hline $\begin{array}{l}\text { Dahlstedtia muehlbergiana (Hassl.) M.J.Silva \& } \\
\text { A.M.G. Azevedo }\end{array}$ & Av & Estéril & FESM, FESA & feijão-cru \\
\hline Dalbergia miscolobium Benth. & Av & 48738,48739 & SA & caviúna-do-cerrado \\
\hline
\end{tabular}


CIELO-FILHO, R. et al. Vegetação da Estação Ecológica de Avaré

continuação - Tabela 2

continuation - Table 2

\begin{tabular}{|c|c|c|c|c|}
\hline FAMÍLIA/Espécie & Hábito & SPSF & Fisionomia & Nome Popular \\
\hline $\begin{array}{l}\text { Hymenaea courbaril var. stilbocarpa (Hayne) } \\
\text { T.Y.Lee \& Langenh. }\end{array}$ & Av & Estéril & FESM & jatobá \\
\hline Inga vera subsp. affinis (DC.) T.D.Penn. & Av & Estéril & FESM & ingá-feijão \\
\hline Leptobium elegans Vogel & Av & 43994,48710 & SA, SGL & amendoim-falso \\
\hline $\begin{array}{l}\text { Leucochloron incuriale (Vell.) Barneby \& } \\
\text { J.W.Grimes }\end{array}$ & Av & Estéril & FESM & chico-pires \\
\hline Machaerium acutifolium Vogel & Av & 48808 & SA, SGL & sapuva, bico-de-pato \\
\hline Machaerium villosum Vogel & Av & Estéril & FESM & jacarandá-paulista \\
\hline Mimosa debilis Humb. \& Bonpl. ex Willd. & $\mathrm{Sb}$ & 48757,48758 & SA, SGL & juquiri \\
\hline Mimosa dollens Vell. & $\mathrm{Sb}$ & 48759,48760 & SA, SGL & juquiri \\
\hline Mimosa somnians Humb. \& Bonpl. ex Willd. & $\mathrm{Sb}$ & 48761,48838 & SA, SGL & juquiri \\
\hline Mimosa xanthocentra Mart. & $\mathrm{Sb}$ & 48762 & SA, SGL & juquiri \\
\hline Ormosia arborea (Vell.) Harms & Av & 48798 & E-SF/FES, SA & olho-de-cabra \\
\hline Parapiptadenia rigida (Benth.) Brenan & Av & Estéril & FESM, FESA & angico-vermelho \\
\hline Piptadenia gonoacantha (Mart.) J.F.Macbr. & $\mathrm{Av}$ & Estéril & $\begin{array}{l}\text { E-SF/FES, } \\
\text { FESM, FESA }\end{array}$ & pau-jacaré \\
\hline Platypodium elegans Vogel & $\mathrm{Av}$ & 44008 & FESM, SA & amendoim-do-campo \\
\hline Pterogyne nitens Tul. & Av & Estéril & FESM & amendoim-bravo \\
\hline Senna multijuga (Rich.) H.S.Irwin \& Barneby & Av & Estéril & FESM & pau-cigarra \\
\hline Senna rugosa (G.Don) H.S.Irwin \& Barneby & Av & 43931,48774 & E-SF/FES & boi-gordo \\
\hline Stryphnodendron adstringens (Mart.) Coville & $\mathrm{Av}$ & $\begin{array}{l}44015,48781 \\
48782\end{array}$ & SA, SGL & barbatimão-verdadeiro \\
\hline Stryphnodendron rotundifolium Mart. & $\mathrm{Av}$ & $\begin{array}{l}44006,48783 \\
\quad 48784\end{array}$ & SA, SGL & barbatimão \\
\hline Zornia crinita (Mohlenbr.) Vanni & $\mathrm{Sb}$ & 48791 & SA, SGL & carrapicho \\
\hline \multicolumn{5}{|l|}{ LAMIACEAE } \\
\hline Aegiphila integrifolia (Jacq.) Moldenke & $\mathrm{Av}, \mathrm{Ab}$ & Estéril & $\begin{array}{c}\text { E-SF/FES, } \\
\text { FESM, FESA, } \\
\text { SA }\end{array}$ & tamanqueira \\
\hline Aegiphila verticillata Vell. & $\mathrm{Av}, \mathrm{Ab}$ & $\begin{array}{l}48712,48713 \\
48714\end{array}$ & SA, SGL & tamanqueira \\
\hline Hyptis campestris Harley \& J.F.B.Pastore & $\mathrm{Sb}$ & 48768 & SA, SGL & papoula-do-campo \\
\hline Hyptis sp. 1 & $\mathrm{Sb}$ & 48805 & SGL & alfavaca-do-campo \\
\hline Hyptis sp. 2 & $\mathrm{Sb}$ & 48840 & SA, SGL & alfavaca-do-campo \\
\hline Vitex megapotamica (Spreng.) Moldenke & $\mathrm{Av}$ & Estéril & FESM & tarumã \\
\hline \multicolumn{5}{|l|}{ LAURACEAE } \\
\hline Aiouea saligna Meisn. & $\mathrm{Av}$ & Estéril & FESM & canela \\
\hline Nectandra grandiflora Nees & $\mathrm{Av}$ & 44020,48796 & FESM, SA & canela-amarela \\
\hline Nectandra lanceolata Nees & $\mathrm{Av}$ & 44019 & FESM, FESA & canela-amarela \\
\hline Nectandra oppositifolia Nees & $\mathrm{Av}$ & Estéril & FESM & canela-ferrugem \\
\hline
\end{tabular}


continuação - Tabela 2

continuation - Table 2

\begin{tabular}{|c|c|c|c|c|}
\hline FAMÍLIA/Espécie & Hábito & SPSF & Fisionomia & Nome Popular \\
\hline Ocotea corymbosa (Meisn.) Mez & Av & $\begin{array}{l}48763,48764 \\
\quad 48809\end{array}$ & $\begin{array}{l}\text { E-SF/FES, FESM, } \\
\text { FESA, SA }\end{array}$ & canelinha \\
\hline Ocotea minarum (Nees \& Mart.) Mez & Av & Estéril & $\begin{array}{l}\text { FESM, FESA, } \\
\text { E-SF/FES }\end{array}$ & canela-vassoura \\
\hline Ocotea pulchella (Nees \& Mart.) Mez & $\mathrm{Av}$ & 43932 & SA & canelinha-lageana \\
\hline Ocotea velutina (Nees) Rohwer & Av & Estéril & SA & canelão \\
\hline Ocotea virgultosa (Nees) Mart. ex Mez & Av & Estéril & SA, SGL & sassafrazinho \\
\hline Ocotea sp. & Av & Estéril & FESM & canela \\
\hline Persea willdenovii Kosterm. & Av & Estéril & $\begin{array}{l}\text { E-SF/FES, FESM, } \\
\text { FESA, SA }\end{array}$ & maçaranduba \\
\hline LECYTHIDACEAE & & & & \\
\hline $\begin{array}{l}\text { Cariniana estrellensis (Raddi) Kuntze } \\
\text { LOGANIACEAE }\end{array}$ & Av & Estéril & FESM & jequitibá-branco \\
\hline $\begin{array}{l}\text { Strychnos brasiliensis Mart. } \\
\text { LYTHRACEAE }\end{array}$ & Av & Estéril & E-SF/FES & salta-martim \\
\hline Lafoensia pacari A.St.-Hil. & $\mathrm{Av}$ & Estéril & $\begin{array}{l}\text { FESM, FESA, } \\
\text { E-SF/FES }\end{array}$ & dedaleiro \\
\hline MAGNOLIACEAE & & & & \\
\hline $\begin{array}{l}\text { Magnolia ovata (A.St.-Hil.) Spreng. } \\
\text { MALPIGHIACEAE }\end{array}$ & Av & Estéril & FESM, FESA & pinha-do-brejo \\
\hline Banisteriopsis campestris (A.Juss.) Little & $\mathrm{Sb}$ & 48720 & SA, SGL & cipó-rosa \\
\hline Banisteriopsis variabilis B.Gates & $\mathrm{Ab}, \mathrm{La}$ & 48721,48722 & SA, SGL & \\
\hline Byrsonima crassifolia (L.) Kunth & $\mathrm{Av}$ & 48727, 48728, & SGL & pau-de-curtume \\
\hline Byrsonima intermedia A.Juss. & $\mathrm{Ab}$ & 43933, 48729 & SGL & murici \\
\hline Peixotoa parviflora A.Juss. & $\mathrm{Ab}, \mathrm{La}$ & 48769 & SA, SGL & cipózinho \\
\hline MALVACEAE & & & & \\
\hline Eriotheca gracilipes (K.Schum.) A.Robyns & $\mathrm{Av}$ & Estéril & SA, SGL & paina-do-campo \\
\hline Luehea divaricata Mart. \& Zucc. & $\mathrm{Av}$ & Estéril & $\begin{array}{l}\text { E-SF/FES, } \\
\text { FESM, FESA }\end{array}$ & açoita-cavalo \\
\hline Luehea grandiflora Mart. \& Zucc. & Av & 48800 & FESM, SA & açoita-cavalo-do-graúdo \\
\hline Peltaea polymorpha (A.St.-Hil.) Krapov. \& Cristóbal & $\mathrm{Ab}, \mathrm{Sb}$ & 48767 & SA, SGL & malva-do-campo \\
\hline Sida cerradoensis Krapov. & $\mathrm{Sb}$ & 48815 & SGL & \\
\hline Sida cf. rhombifolia L. & $\mathrm{Hr}$ & 48819 & SA, SGL & guanxuma \\
\hline Sida viarum A.St.-Hil. & $\mathrm{Sb}$ & 48776 & SA, SGL & guanxuma \\
\hline Triumfetta semitriloba Jacq. & $\mathrm{Sb}$ & 48827 & SA, SGL & triunfeta \\
\hline $\begin{array}{l}\text { Waltheria indica } \mathrm{L} \text {. } \\
\text { MELASTOMATACEAE }\end{array}$ & $\mathrm{Hr}, \mathrm{Sb}$ & 48789,48790 & SGL & malva-veludo \\
\hline Miconia albicans (Sw.) Triana & $\mathrm{Av}, \mathrm{Ab}$ & $\begin{array}{l}43934,44000 \\
\quad 48754\end{array}$ & SGL & quaresmeira-branca \\
\hline Miconia cinerascens Miq. & $\mathrm{Av}, \mathrm{Ab}$ & Estéril & FESM & jacatirão, pixiricão \\
\hline Miconia fallax DC. & $\mathrm{Ab}$ & 48816,48845 & SA, SGL & quaresmeira \\
\hline
\end{tabular}


CIELO-FILHO, R. et al. Vegetação da Estação Ecológica de Avaré

continuação - Tabela 2

continuation - Table 2

\begin{tabular}{|c|c|c|c|c|}
\hline FAMÍLIA/Espécie & Hábito & SPSF & Fisionomia & Nome Popular \\
\hline Miconia ligustroides (DC.) Naudin & $\mathrm{Av}, \mathrm{Ab}$ & $\begin{array}{l}43935,44901 \\
48756\end{array}$ & SA, SGL & jacatirão-do-cerrado \\
\hline Miconia paucidens DC. & $\mathrm{Av}, \mathrm{Ab}$ & Estéril & SA, SGL & jacatirão-langsdorfi \\
\hline Miconia sellowiana Naudin & $\mathrm{Av}$ & 44001 & SA, SGL & pixirica \\
\hline Miconia stenostachya DC. & $\mathrm{Ab}$ & Estéril & SA, SGL & papaterra \\
\hline Tibouchina stenocarpa (Schrank \& Mart. ex. DC.) Cogn. & Av & $\begin{array}{l}48787,48788 \\
\quad 48844\end{array}$ & SA, SGL & quaresmeira \\
\hline \multicolumn{5}{|l|}{ MELIACEAE } \\
\hline Cabralea canjerana (Vell.) Mart. subsp. canjerana & $\mathrm{Av}$ & Estéril & FESM & canjerana \\
\hline Cedrela fissilis Vell. & Av & Estéril & FESM & cedro-rosa \\
\hline Trichilia elegans A.Juss. subsp. elegans & Av & Estéril & FESM & chal-chal \\
\hline Trichilia pallida $\mathrm{Sw}$ & Av & 43946 & FESM & chal-chal \\
\hline MORACEAE & & & & \\
\hline $\begin{array}{l}\text { Sorocea bonplandii (Baill.) W.C.Burger et al. } \\
\text { MYRTACEAE }\end{array}$ & Av & Estéril & FESM & canxim \\
\hline Calyptranthes concinna DC. & $\mathrm{Av}$ & Estéril & FESM & guamirim-facho \\
\hline Campomanesia adamantium (Cambess.) O.Berg & Av & 44021 & $\begin{array}{l}\text { FESM, FESA, } \\
\text { E-SF/FES }\end{array}$ & gabiroba \\
\hline Campomanesia grandiflora (Aubl.) Sagot & Av & 48851 & SA, SGL & araçá, \\
\hline Campomanesia guazumifolia (Cambess.) O.Berg & Av & Estéril & SA, SGL & sete-capotes \\
\hline Campomanesia xanthocarpa (Mart.) O.Berg & Av & Estéril & SA & gabirobeira \\
\hline Eucalyptus grandis W.Hill * & Av & Estéril & $\begin{array}{c}\text { E-SF/FES, } \\
\text { FESM, FESA, } \\
\text { SA, SGL }\end{array}$ & eucalipto \\
\hline Eugenia aurata O.Berg & Av & 48811,48849 & SA, SGL & murtinha \\
\hline Eugenia hiemalis Cambess. & Av & 48853 & SA, SGL & guamirim-do-campo \\
\hline Eugenia punicifolia (Kunth) DC. & Av & 48855,48856 & SA, SGL & cereja-do-cerrado \\
\hline Eugenia pyriformis Cambess. & Av & $\begin{array}{l}44022,48857 \\
48858\end{array}$ & SA, SGL & uvaia \\
\hline Myrcia albotomentosa DC. & $\mathrm{Ab}$ & 48848 & SA, SGL & guamirim \\
\hline Myrcia guianensis (Aubl.) DC. & $\mathrm{Av}$ & 44011 & SA, SGL & brasa-viva \\
\hline Myrcia hebepetala DC. & Av & Estéril & SA & $\begin{array}{l}\text { guamirim- } \\
\text {-aperta-goela }\end{array}$ \\
\hline Myrcia multiflora (Lam.) DC. & $\mathrm{Av}, \mathrm{Ab}$ & 44007 & E-SF/FES, SA & cambuí \\
\hline Myrcia pulchra (O.Berg) Kiaersk. & Av & 43936 & SA, SGL & guamirim \\
\hline Myrcia sp.1 & Av & 48847 & SA, SGL & \\
\hline Myrcia sp.2 & $\mathrm{Av}$ & 43953 & SA & \\
\hline Myrciaria delicatula (DC.) O.Berg & $\mathrm{Av}$ & 48852 & SA, SGL & cambuí \\
\hline Myrciaria floribunda (H.West ex Willd.) O.Berg & Av & Estéril & SA, SGL & cambuí \\
\hline Myrciaria tenella $(\mathrm{DC}$.$) O.Berg$ & Av & Estéril & FESM & cambuí \\
\hline Myrciaria sp. & Av & Estéril & FESM & \\
\hline Psidium sp. & Av & 48846 & SA, SGL & \\
\hline
\end{tabular}


continuação - Tabela 2

continuation - Table 2

\begin{tabular}{|c|c|c|c|c|}
\hline FAMÍLIA/Espécie & Hábito & SPSF & Fisionomia & Nome Popular \\
\hline \multicolumn{5}{|l|}{ OCHNACEAE } \\
\hline Ouratea spectabilis (Mart.) Engl. & $\mathrm{Av}$ & 44009 & SA & batiputá \\
\hline \multicolumn{5}{|l|}{ ORCHIDACEAE } \\
\hline Galeandra sp. & $\mathrm{Hr}$ & 48826 & E-SF/FES & \\
\hline \multicolumn{5}{|l|}{ PERACEAE } \\
\hline Pera glabrata (Schott) Poepp. ex Baill. & $\mathrm{Av}, \mathrm{Ab}$ & 48770,48797 & E-SF/FES, SA & sapateiro \\
\hline \multicolumn{5}{|l|}{ PINACEAE } \\
\hline Pinus sp. * & Av & Estéril & SA & pinus \\
\hline \multicolumn{5}{|l|}{ POACEAE } \\
\hline Andropogon bicornis $\mathrm{L}$. & $\mathrm{Hr}$ & 48828 & SGL & rabo-de-burro \\
\hline Andropogon selloanus (Hack.) Hack. & $\mathrm{Hr}$ & 48832,48837 & SA, SGL & capim-membeca \\
\hline Gymnopogon foliosus (Willd.) Nees & $\mathrm{Hr}$ & 48833 & SGL & \\
\hline Imperata brasiliensis Trin. & $\mathrm{Hr}$ & Estéril & SA, SGL & capim-sapé \\
\hline Melinis minutiflora P.Beauv. * & $\mathrm{Hr}$ & Estéril & SA, SGL & capim-gordura \\
\hline Panicum campestre Nees ex Trin. & $\mathrm{Hr}$ & 48836 & SA, SGL & $\begin{array}{c}\text { colchão- } \\
\text {-pé-de-galinha }\end{array}$ \\
\hline Panicum sellowii Nees & $\mathrm{Hr}$ & 48835 & SGL & bambuzinho \\
\hline Schizachyrium sanguineum (Retz.) Alston & $\mathrm{Hr}$ & 48830 & SGL & \\
\hline Setaria scabrifolia (Nees) Kunth & $\mathrm{Hr}$ & 44831,48834 & SA, SGL & \\
\hline $\begin{array}{l}\text { Urochloa brizantha (Hochst. ex A.Rich.) R.D. } \\
\text { Webster* }\end{array}$ & $\mathrm{Hr}$ & 48829 & SA, SGL & braquiária \\
\hline \multicolumn{5}{|l|}{ POLYGONACEAE } \\
\hline Coccoloba mollis Casar. & Av & Estéril & SA & falso-novateiro \\
\hline Coccoloba sp. & Av & Estéril & SA, SGL & \\
\hline \multicolumn{5}{|l|}{ PRIMULACEAE } \\
\hline Myrsine coriacea (Sw.) R.Br. ex Roem. \& Schult. & $\mathrm{Av}, \mathrm{Ab}$ & Estéril & FESM & capororoca \\
\hline Myrsine gardneriana A.DC. & $\mathrm{Av}, \mathrm{Ab}$ & Estéril & FESM & capororoca \\
\hline Myrsine umbellata Mart. & Av & Estéril & $\begin{array}{l}\text { E-SF/FES, } \\
\text { FESM, FESA }\end{array}$ & capororocão \\
\hline Myrsine sp. & Av & Estéril & SA, SGL & capororoca \\
\hline \multicolumn{5}{|l|}{ PROTEACEAE } \\
\hline $\begin{array}{l}\text { Roupala montana Aubl. } \\
\text { ROSACEAE }\end{array}$ & \multicolumn{3}{|c|}{ ROSACEAE } & carne-de-vaca \\
\hline $\begin{array}{l}\text { Prunus myrtifolia (L.) Urb. } \\
\text { RUBIACEAE }\end{array}$ & \multicolumn{3}{|c|}{ RUBIACEAE } & pessegueiro-bravo \\
\hline Amaioua intermedia Mart. ex Schult. \& Schult.f. & $\mathrm{Av}, \mathrm{Ab}$ & $\begin{array}{l}43937,48717 \\
\quad 48718\end{array}$ & E-SF/FES, SA & café-do-mato \\
\hline Borreria verticillata (L.) G.Mey. & $\mathrm{Sb}$ & $\begin{array}{l}48725,48726 \\
\quad 48821\end{array}$ & SGL & $\begin{array}{l}\text { vassourinha- } \\
\text {-de-botão }\end{array}$ \\
\hline Chomelia parvifolia (Standl.) Govaerts & $\mathrm{Av}, \mathrm{Ab}$ & Estéril & FESM & \\
\hline Chomelia sp.1 & $\mathrm{Av}, \mathrm{Ab}$ & Estéril & SA, SGL & \\
\hline
\end{tabular}


CIELO-FILHO, R. et al. Vegetação da Estação Ecológica de Avaré

continuação - Tabela 2

continuation - Table 2

\begin{tabular}{|c|c|c|c|c|}
\hline FAMÍLIA/Espécie & Hábito & SPSF & Fisionomia & Nome Popular \\
\hline Chomelia sp.2 & $\mathrm{Av}, \mathrm{Ab}$ & Estéril & SA, SGL & \\
\hline Cordiera concolor (Cham.) Kuntze & $\mathrm{Ab}, \mathrm{Sb}$ & Estéril & SA & $\begin{array}{l}\text { marmelinho- } \\
\text {-do-campo }\end{array}$ \\
\hline Cordiera sessilis (Vell.) Kuntze & Av & 48716 & SA, SGL & $\begin{array}{l}\text { marmelinho- } \\
\text {-do-campo }\end{array}$ \\
\hline Cordiera sp. & Av & Estéril & SA, SGL & \\
\hline $\begin{array}{l}\text { Declieuxia cordigera Mart. \& Zucc. ex Schult. \& } \\
\text { Schult.f. }\end{array}$ & $\mathrm{Hr}$ & 48741 & SA, SGL & \\
\hline Guettarda uruguensis Cham. \& Schltdl. & $\mathrm{Ab}$ & 43948 & FESM & veludinha \\
\hline Ixora venulosa Benth. & $\mathrm{Av}, \mathrm{Ab}$ & Estéril & FESM & \\
\hline Manettia cordifolia Mart. & $\mathrm{La}$ & 48752 & SA, SGL & \\
\hline Palicourea croceoides Ham. & $\mathrm{Ab}, \mathrm{Sb}$ & 48768 & SA, SGL & erva-de-rato \\
\hline Palicourea marcgravii A.St.-Hil. & $\mathrm{Ab}$ & 43992 & FESM & erva-de-rato \\
\hline Palicourea rigida Kunth & $\mathrm{Ab}, \mathrm{Sb}$ & 48766 & SA, SGL & erva-de-rato \\
\hline Psychotria vellosiana Benth. & $\mathrm{Av}, \mathrm{Ab}$ & 43949 & FESM & erva-de-rato \\
\hline Randia armata (Sw.) DC. & $\mathrm{Av}, \mathrm{Ab}$ & Estéril & FESM & limoeiro-do-mato \\
\hline Rudgea jasminoides (Cham.) Müll. Arg. & $\mathrm{Av}, \mathrm{Ab}$ & Estéril & FESM & \\
\hline Rudgea sp. & Av & 43952 & SA & \\
\hline $\begin{array}{l}\text { Tocoyena formosa (Cham. \& Schltdl.) K.Schum. } \\
\text { RUTACEAE }\end{array}$ & $\mathrm{Av}, \mathrm{Ab}$ & 48793 & SA & jenipapo-bravo \\
\hline Esenbeckia febrifuga (A.St.-Hil.) A.Juss. ex Mart. & $\mathrm{Av}$ & 43950 & FESM & pau-de-cutia \\
\hline $\begin{array}{l}\text { Zanthoxylum rhoifolium Lam. } \\
\text { SALICACEAE }\end{array}$ & Av & Estéril & FESM & mamica-de-porca \\
\hline Casearia decandra Jacq. & $\mathrm{Av}, \mathrm{Ab}$ & Estéril & FESM & guaçatonga \\
\hline Casearia sylvestris Sw. & $\mathrm{Av}, \mathrm{Ab}$ & Estéril & FESM & guaçatonga \\
\hline Xylosma glaberrima Sleumer & $\mathrm{Av}$ & Estéril & FESM & \\
\hline SAPINDACEAE & & & & \\
\hline Allophylus edulis (A.St.-Hil. et al.) Hieron. ex Niederl. & $\mathrm{Av}, \mathrm{Ab}$ & Estéril & FESM & chal-chal \\
\hline Cupania vernalis Cambess. & $\mathrm{Av}$ & 44018 & FESM & camboatã \\
\hline Matayba elaeagnoides Radlk. & $\mathrm{Av}, \mathrm{Ab}$ & Estéril & $\begin{array}{l}\text { E-SF/FES, FESM, } \\
\text { FESA, SA }\end{array}$ & cuvantã \\
\hline $\begin{array}{l}\text { Serjania sp. } \\
\text { SAPOTACEAE }\end{array}$ & $\mathrm{La}$ & 48803 & E-SF/FES, SGL & \\
\hline Chrysophyllum marginatum (Hook. \& Arn.) Radlk. & $\mathrm{Av}, \mathrm{Ab}$ & 43951,48737 & SA, SGL & aguaí \\
\hline Pouteria torta (Mart.) Radlk. & $\mathrm{Av}, \mathrm{Ab}$ & 48799 & SA & abiu-do-cerrado \\
\hline $\begin{array}{l}\text { Pradosia brevipes (Pierre) T.D.Penn. } \\
\text { SIPARUNACEAE }\end{array}$ & $\mathrm{Ab}$ & Estéril & SA, SGL & fruta-de-tatu \\
\hline Siparuna brasiliensis (Spreng.) A.DC. & $\mathrm{Av}, \mathrm{Ab}$ & 44014 & FESM, FESA, SA & limão-bravo \\
\hline $\begin{array}{l}\text { Siparuna guianensis Aubl. } \\
\text { SMILACACEAE }\end{array}$ & $\mathrm{Av}, \mathrm{Ab}$ & 43938 & SA & limão-bravo \\
\hline Smilax polyantha Griseb. & $\mathrm{La}$ & 48777,48778 & SGL & $\begin{array}{l}\text { japecanga } \\
\text { continu } \\
\text { to be continue }\end{array}$ \\
\hline
\end{tabular}


continuação - Tabela 2

continuation - Table 2

\begin{tabular}{|c|c|c|c|c|}
\hline FAMÍLIA/Espécie & Hábito & SPSF & Fisionomia & Nome Popular \\
\hline \multicolumn{5}{|l|}{ SOLANACEAE } \\
\hline Solanum lycocarpum A.St.-Hil. & $\mathrm{Av}, \mathrm{Ab}$ & 48779 & SA, SGL & fruta-de-lobo \\
\hline Solanum mauritianum Scop. & $\mathrm{Av}, \mathrm{Ab}$ & Estéril & SA, SGL & \\
\hline Solanum paniculatum $\mathrm{L}$. & $\mathrm{Ab}$ & 48780 & SA, SGL & jurubeba \\
\hline \multicolumn{5}{|l|}{ SYMPLOCACEAE } \\
\hline Symplocos pubescens Klotzsch ex Benth. & $\mathrm{Av}, \mathrm{Ab}$ & Estéril & SGL & pau-de-cinza \\
\hline \multicolumn{5}{|l|}{ THYMELAEACEAE } \\
\hline Daphnopsis racemosa Griseb. & $\mathrm{Av}, \mathrm{Ab}$ & Estéril & FESM & embira-branca \\
\hline Daphnopsis utilis Warm. & $\mathrm{Av}, \mathrm{Ab}$ & 43954 & SA & embira-branca \\
\hline \multicolumn{5}{|l|}{ URTICACEAE } \\
\hline Cecropia pachystachya Trécul & Av & Estéril & FESM, FESA & embaúba \\
\hline \multicolumn{5}{|l|}{ VERBENACEAE } \\
\hline Lippia origanoides Kunth & $\mathrm{Ab}, \mathrm{Sb}$ & 48751,48820 & SA, SGL & \\
\hline \multicolumn{5}{|l|}{ VIOLACEAE } \\
\hline Pombalia bigibbosa (A.St.-Hil.) Paula-Souza & $\mathrm{Ab}, \mathrm{Sb}$ & Estéril & FESM & \\
\hline \multicolumn{5}{|l|}{ VOCHYSIACEAE } \\
\hline Qualea cordata (Mart.) Spreng. & $\mathrm{Av}$ & 43939 & SA & carvãozinho \\
\hline Qualea grandiflora Mart. & $\mathrm{Av}$ & 48772 & SA, SGL & pau-terra \\
\hline Vochysia tucanorum Mart. & $\mathrm{Av}$ & 48802 & FESM, FESA, SA & pau-de-tucano \\
\hline
\end{tabular}

O número de espécies registrado na Estação Ecológica de Avaré ficou abaixo do verificado na Estação Ecológica de Itapeva, onde foram registradas 483 espécies (Cielo-Filho et al., 2011). As duas unidades se assemelham no tocante à composição fitofisionômica, porém, a unidade de Itapeva apresenta maior complexidade de fisionomias vegetais, devido à ocorrência de solos com maior saturação hídrica, o que pode ser apontado como uma das causas para a maior riqueza observada naquela unidade.Outro aspecto a ser considerado refere-se ao histórico de perturbação, sendo que as alterações do ambiente natural na Estação Ecológica de Avaré foram muito mais profundas, extensas e recentes, demandando mais tempo para que os processos ecológicos ligados à resiliência dos ecossistemas locais recuperem a diversidade. Contudo, provavelmente, o principal fator responsável pela diferença na riqueza registrada nas duas unidades é o maior esforço de coleta em Itapeva, onde os levantamentos de dados primários e secundários resultaram em 282 e 344 espécies, respectivamente.

O número relativamente baixo de espécies registradas por dados secundários na Estação Ecológica de Avaré (três) reforça que a flora dessa unidade é ainda subamostrada e que os esforços de coleta precisam continuar ainda por mais tempo, mesmo após a conclusão do seu plano de manejo. As Estações Ecológicas de Assis (Durigan, 2008) e de Santa Bárbara (Melo e Durigan, 2011) também apresentam composição fitofisionômica semelhante, embora mais complexa que a Estação Ecológica de Avaré, o que contribuiu, juntamente com o maior esforço amostral, para a maior riqueza registrada nessas unidades, 576 e 528 espécies, respectivamente.

\subsubsection{Espécies invasoras}

Nos levantamentos efetuados na Estação Ecológica de Avaré constatou-se a ocorrência de espécies exóticas invasoras como a braquiária - Urochloa brizantha e o capim-gordura-Melinis minutiflora. O potencial invasor dessas duas gramíneas exóticas é reconhecido para várias fisionomias campestres ou florestais no Brasil (Zenni e Ziller, 2011). Também ocorrem na EEcA espécies nativas com comportamento invasor ou espécies-problema, representadas pela samambaia-do-campo - Pteridium arachnoideum e o capim-sapé - Imperata brasiliensis. Na Unidade, também são encontradas essências florestais exóticas como Pinus sp. e o eucalipto - Eucalyptus grandis. 
A braquiária apresenta comportamento oportunista que lhe permite deslocar competitivamente espécies nativas do cerrado, recolonizando rapidamente áreas queimadas e/ou perturbadas (Baruch et al., 1985; D’Antonio e Vitousek, 1992; Freitas, 1999; Pivello et al., 1999). Na Estação Ecológica de Avaré, a braquiária ocorre nas margens de estradas, nos aceiros e locais mais abertos surgindo por entre a vegetação, onde o solo se encontra mais exposto (Figura 10). Os prováveis vetores de dispersão das gramíneas exóticas na Unidade são os veículos que circulam pelas estradas internas e a utilização indevida da área para pastoreio de bovinos. As sementes trazidas por tais vetores para o interior da Estação são oriundas das pastagens situadas no seu entorno.

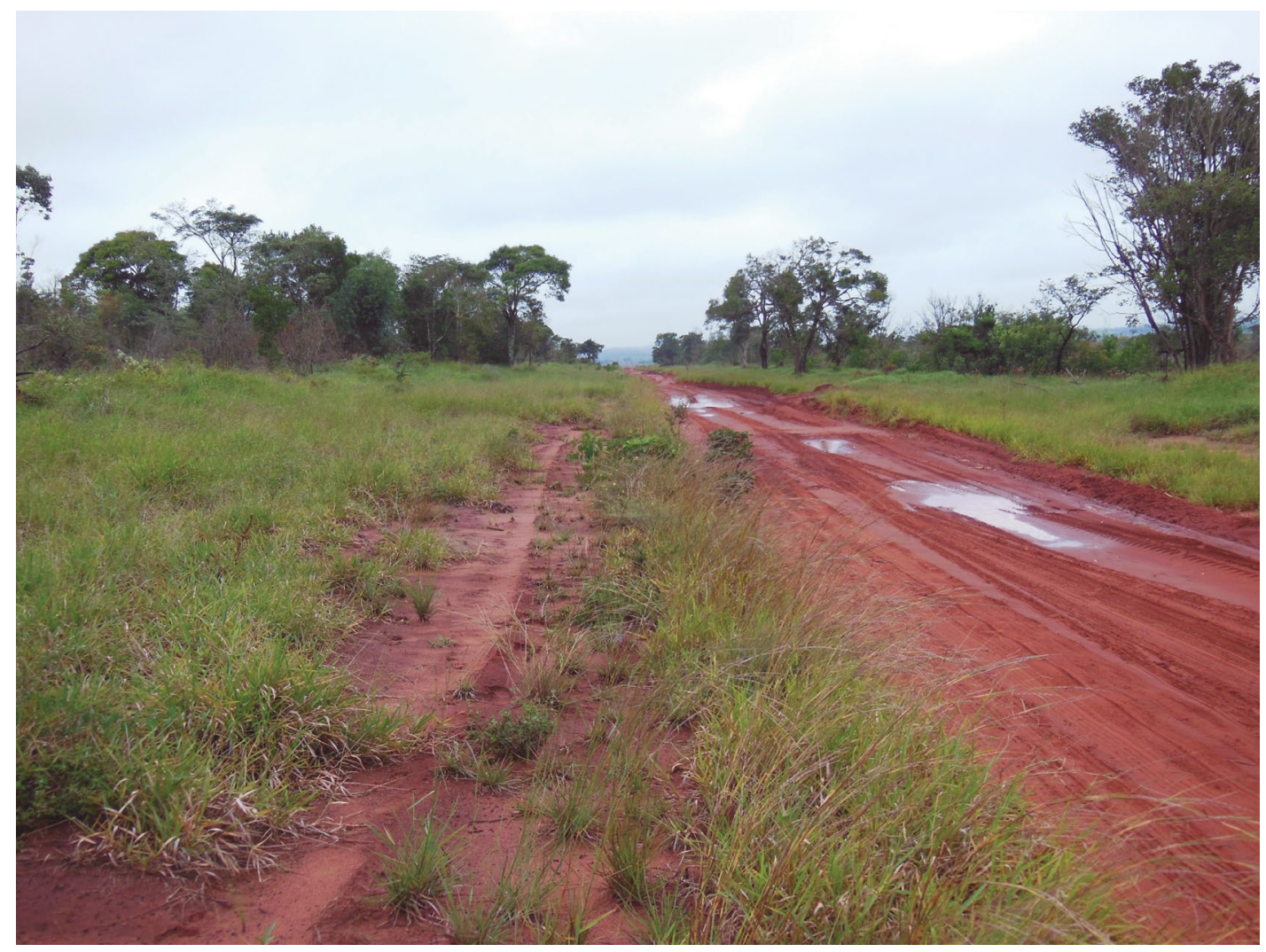

Figura 10. Invasão de braquiária na Estação Ecológica de Avaré - SP. (Foto: J.B. Baitello).

Figure 10. Invasion of braquiária in the Avaré Ecological Station - SP. (Photo: J.B. Baitello).

O capim-gordura é uma invasora extremamente agressiva com alta capacidade competitiva e de dispersão que pode provocar alterações fitofisionômicas na vegetação (Filgueiras, 1990; Martins et al., 2004), contribuir para a alteração do regime de fogo local (Hughes et al., 1991) e reduzir a germinação e/ou o crescimento de mudas por efeito alelopático (Hoffman e Haridasan, 2008). A espécie é reconhecida como uma das mais frequentes, considerando o conjunto das formações vegetais brasileiras, e particularmente relevante nas formações de Cerrado (Zenni e Ziller, 2011). Na Estação Ecológica de Avaré, o capim-gordura ocorre na forma de manchas em meio a locais mais abertos da vegetação nativa, nas margens dos caminhos; também ocorre em associação com a braquiária e nas bordas dos samambaiais (Figura 11).

As samambaias, pertencentes ao gênero Pteridium, apresentam ampla distribuição global, ocorrendo em diferentes ecossistemas (Rassmussen, 2003). Entre elas, destaca-se a espécie Pteridium aquilinum (L) Kuhn, por suas propriedades carcinogênicas para animais (Shahin et al., 1999; Alonso-Amelot et al., 2001). Propriedade semelhante foi encontrada na samambaia-do-campo, $P$. arachnoideum. Os vastos campos ocupados por esta samambaia, em algumas regiões da Estação (Figura 12), aumentam o risco de seu componente carcinogênico contaminar o solo e a água pelo processo de lixiviação e pode representar um risco ambiental para a saúde animal, incluindo-se a humana. 


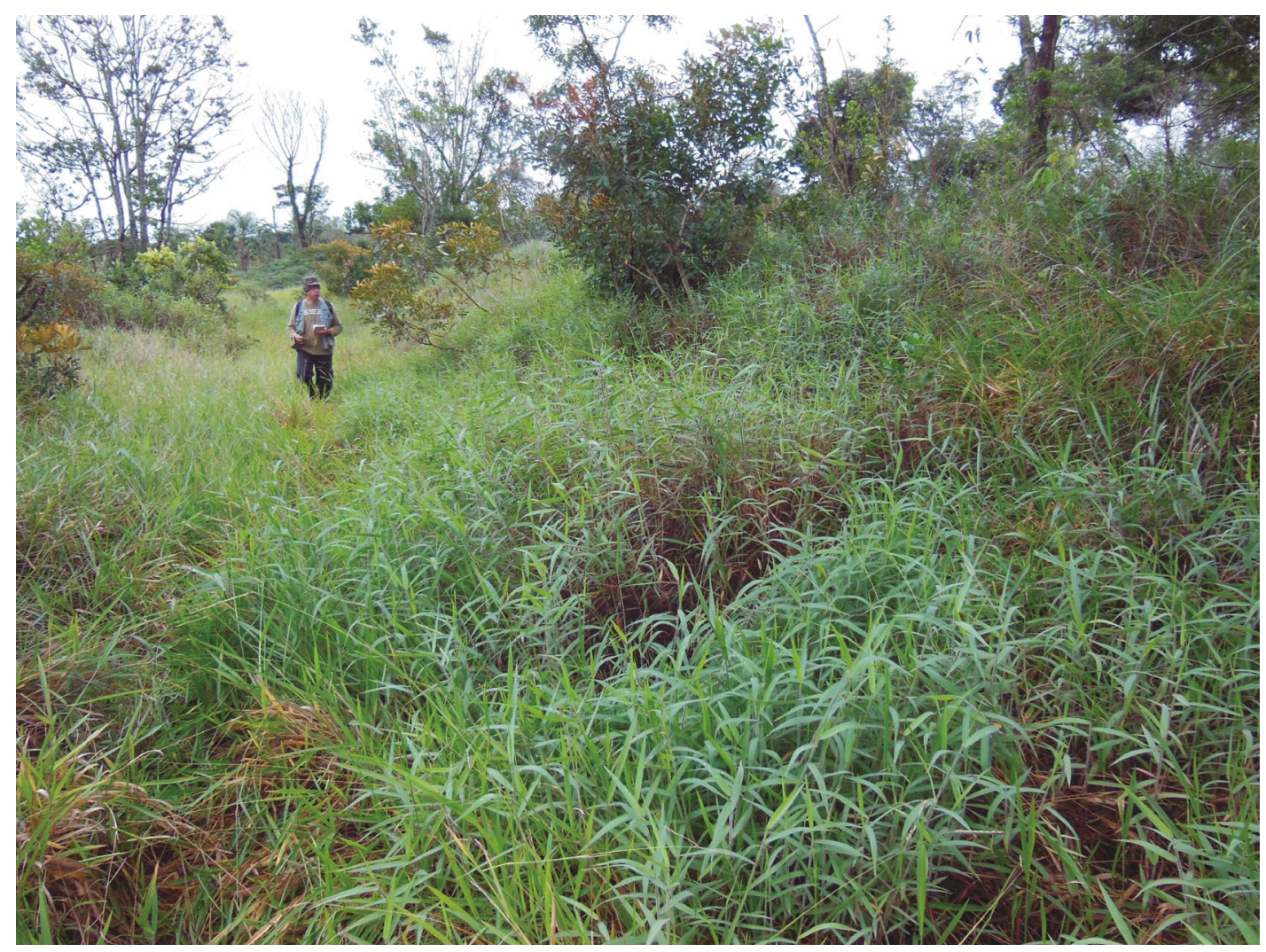

Figura 11. Invasão de capim-gordura na Estação Ecológica de Avaré - SP. (Foto: F.S.P. Vilela).

Figure 11. Invasion of capim-gordura in the Avaré Ecological Station - SP. (Photo: F.S.P. Vilela).

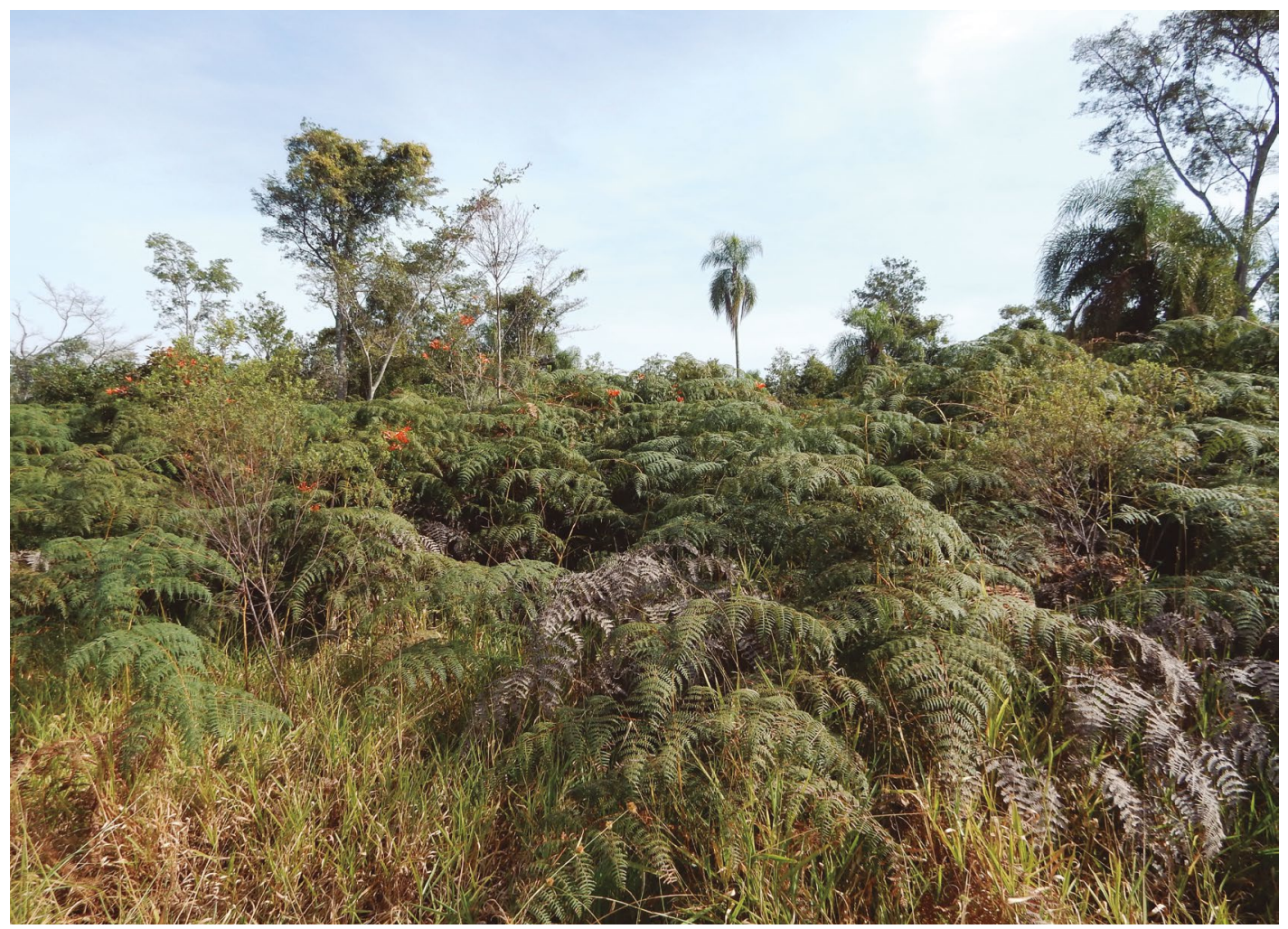

Figura 12. Invasão de samambaia-do-campo na Estação Ecológica de Avaré - SP. (Foto: F.S.P. Vilela).

Figure 12. Invasion of samambaia-do-campo in the Avaré Ecological Station - SP. (Photo: F.S.P. Vilela). 
O capim-sapé é outra espécie favorecida por perturbações da vegetação natural, adaptando-se muito bem à situação pós-perturbação e disseminando-se facilmente por meio de reprodução vegetativa, o que dificulta o seu controle (Fontes e Shiratsuchi, 2014). Na Estação Ecológica de Avaré, o capim-sapé ocupa áreas relativamente extensas de fisionomias campestres formando densos agrupamentos (Figura 13).

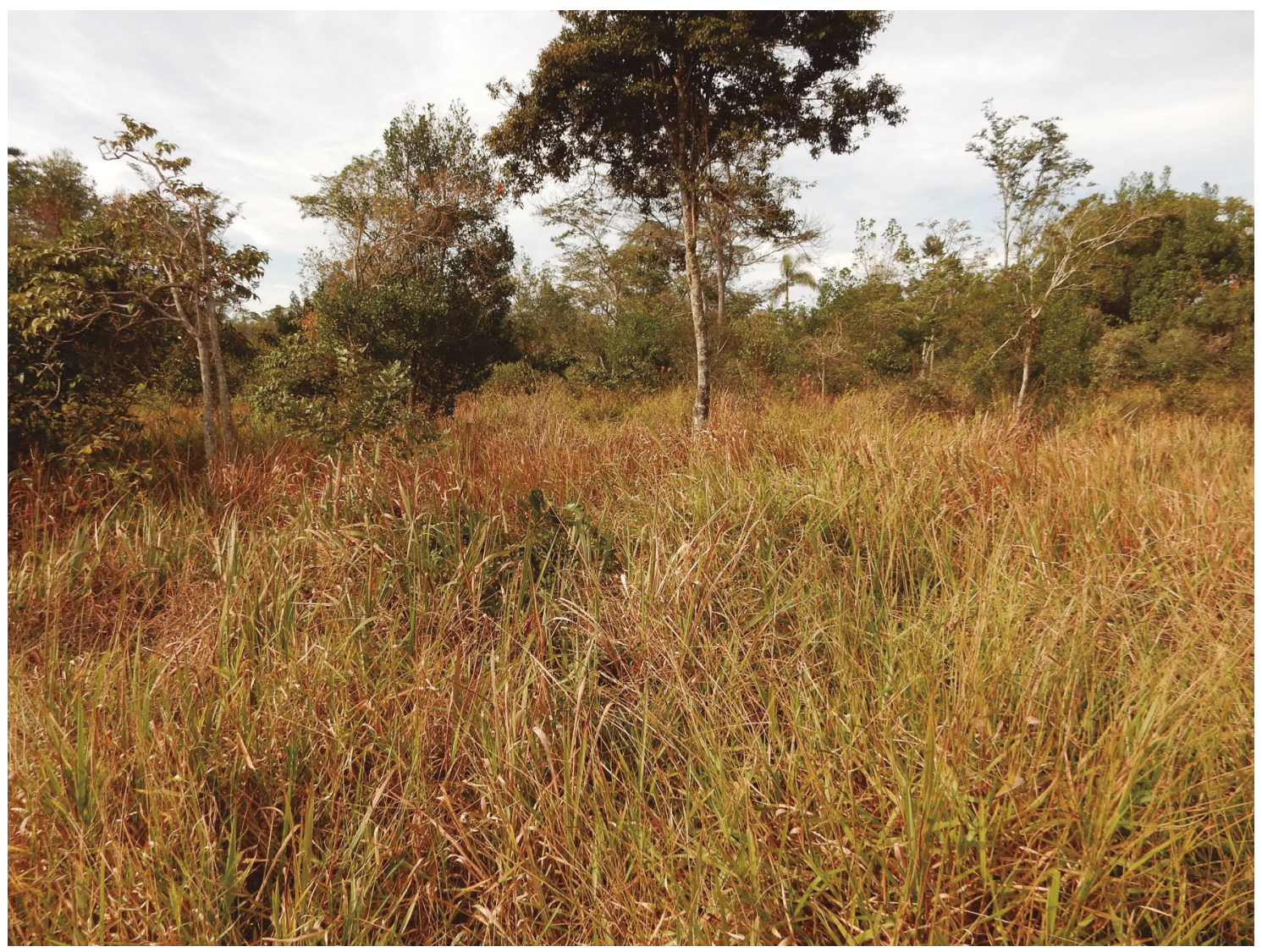

Figura 13. Invasão de capim-sapé na Estação Ecológica de Avaré - SP. (Foto: F.S.P. Vilela).

Figure 13. Invasion of capim-sapé in the Avaré Ecological Station - SP. (Photo: F.S.P. Vilela).

Algumas espécies do gênero Pinus estão entre as que apresentam maior potencial de invasão de ambientes naturais (Zalba et al., 2008). Características como a dispersão das sementes pelo vento, crescimento rápido, alta produtividade de sementes e ciclo de manejo longo estão associadas ao sucesso das invasões biológicas dessas espécies no hemisfério Sul (Higgins e Richardson, 1998). $\mathrm{Na}$ Estação Ecológica de Avaré, próximo ao antigo cemitério, ocorrem alguns indivíduos de Pinus sp. adultos que podem ter sido implantados intencionalmente ou dispersos de povoamentos próximos. Pode-se observar, entretanto, alguns indivíduos jovens sobressaindo na vegetação de cerrado (Figura 6) provavelmente em razão da dispersão por sementes produzidas pelos adultos. Em razão de ocorrerem poucos indivíduos, seu controle ou erradicação pode ser facilitado.

Os indivíduos de eucalipto encontram-se disseminados em alguns trechos da área da Estação Ecológica de Avaré, originando-se por meio de rebrota dos indivíduos plantados pela Estrada de Ferro Sorocabana, detentora anterior da área. Próximo ao antigo cemitério, observa-se um pequeno agrupamento de tais indivíduos (Figuras 2 e 14). Em grande parte da Unidade encontram-se cepas de eucalipto sem capacidade de rebrota, testemunhos da intensa atividade silvicultural que ali se desenvolveu. Contudo, algumas cepas de indivíduos cortados mais recentemente apresentam rebrotas, havendo necessidade de erradicação dessas brotações. Não há indícios de dispersão da espécie por sementes. 


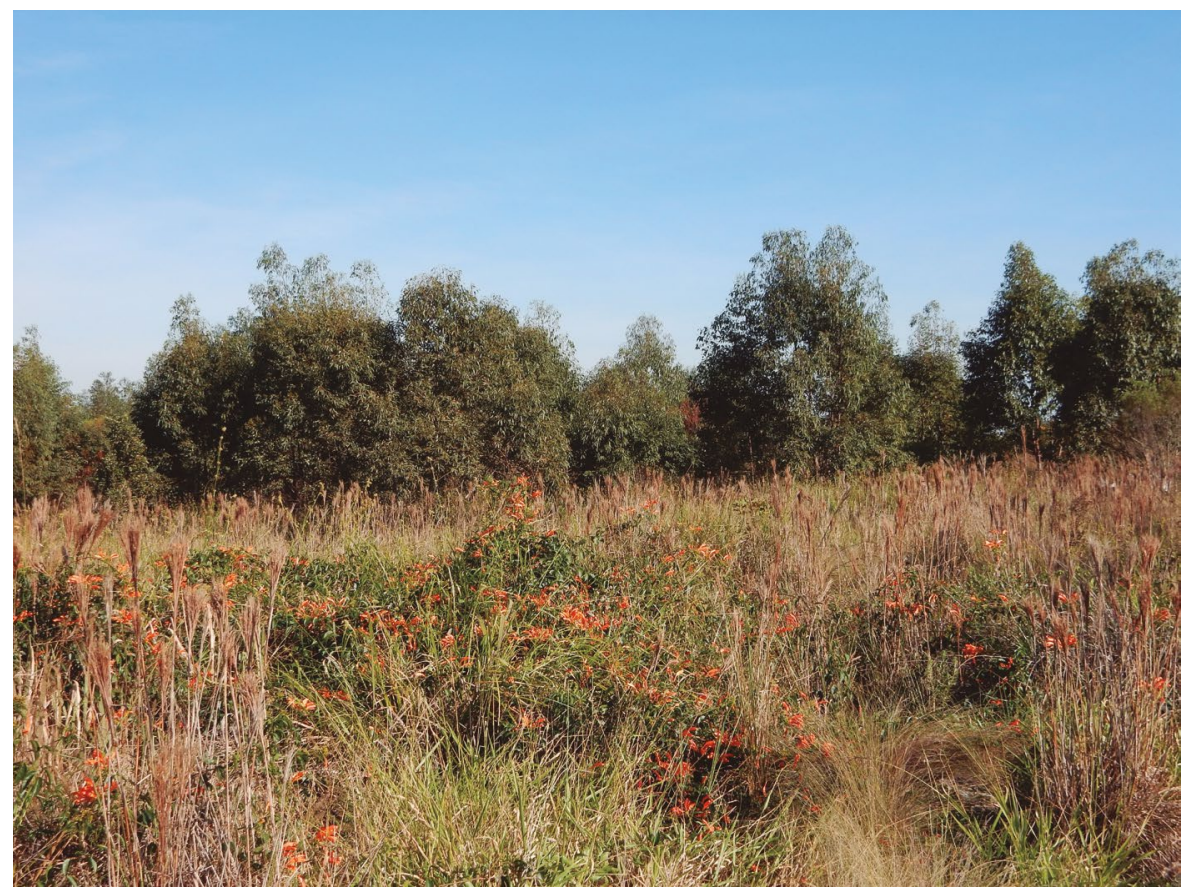

Figura 14. Invasão de eucalipto na Estação Ecológica de Avaré - SP. (Foto: F.S.P. Vilela).

Figure 14. Invasion of eucalyptus in the Avaré Ecological Station - SP. (Photo: F.S.P. Vilela).

\subsubsection{Espécies raras e ameaçadas de extinção}

O objetivo das listas de espécies ameaçadas é orientar as ações políticas, conservacionistas e científicas voltadas à proteção da biodiversidade. As listas são o primeiro passo para a conservação das espécies, pois implicam na capacidade de monitorar o status de ameaça da biodiversidade (IUCN, 2001). Tais espécies recebem tutela legal da legislação ambiental brasileira (Brasil, 1998; Brasil, 2014) e internacional (Brasil, 2000b).

A criação e manutenção de unidades de conservação estão entre as principais medidas para a proteçãode espécies e habitats ameaçados e reversão da tendência de extinção. A presença de tais espécies em uma unidade de conservação representa, portanto, não apenas um atestado de significância da unidade, mas também um desafio de gestão. Uma vez detectada a presença de espécies ameaçadas, ações visando à pesquisa e ao monitoramento devem ser implementadas, de modo a fornecer subsídios para programas de conservação. Uma linha de pesquisa considerada prioritária é o estudo da biologia reprodutiva dessas espécies, com vistas a subsidiar programas de recuperação populacional. Dados demográficos e ecológicos da espécie também são necessários, tais como densidade, frequência, taxas de natalidade e mortalidade, habitat preferencial, inimigos naturais etc. As ações de conservação abrangem diversas classes de iniciativas. A classificação das ações de conservação, de acordo com a IUCN, pode ser encontrada em Martinelli e Moraes (2013).

Entre as espécies nativas registradas na Estação, cinco foram enquadradas em alguma categoria de ameaça (Tabela 3). A maior parte das ameaças envolve a perda de habitat, o que é preocupante, pois a manutenção em longo prazo da viabilidade das populações de espécies ameaçadas dentro de unidades de conservação depende de trocas gênicas com outras populações coespecíficas que se encontram fora da unidade. Nesse sentido, a conservação da maior parte de remanescentes de habitat e o estabelecimento de corredores ecológicos em escala de paisagem e regional são medidas necessárias. Na delimitação da Zona de Amortecimento da EEcA foram incluídos remanescentes de vegetação natural que poderão ser conectados à UC. Em escala regional, serão necessários estudos adicionais, porém, com base nas recomendações obtidas em Rodrigues e Bononi (2008), é possível vislumbrar um corredor de biodiversidade interligando as Estações Ecológicas de Avaré e Santa Bárbara e, em escala mais ampla, formando um arco abrangendo as cuestas basálticas entre Botucatu e São Carlos, a nordeste, e a bacia hidrográfica do rio do Peixe, a oeste. 
CIELO-FILHO, R. et al. Vegetação da Estação Ecológica de Avaré

Tabela 3. Espécies registradas na Estação Ecológica de Avaré enquadradas em alguma categoria de ameaça segundo as listas IUCN, MMA e SMA-SP: EX, Extinta; EN, Ameaçada; VU, Vulnerável; ou consideradas espécies raras (CI-Brasil).

Table 3. Threatened species recorded in Avaré Ecological Station according to IUCN, MMA and SMA-SP: EX, Extinct; EN, Threatened; VU, Vulnerable; or considered as rare species (CI-Brasil).

\begin{tabular}{|c|c|c|c|c|c|}
\hline FAMÍLIA/Espécie & IUCN & MMA & SMA-SP & CI-Brasil & Ameaça ou justificativa* \\
\hline \multicolumn{6}{|l|}{ BIGNONIACEAE } \\
\hline Anemopaegma arvense & & EN & & & Perda de habitat, exploração, declínio populacional \\
\hline \multicolumn{6}{|l|}{ CONNARACEAE } \\
\hline Rourea pseudospadicea & & EN & & Rara & Perda de habitat, área de ocupação restrita \\
\hline \multicolumn{6}{|l|}{ FABACEAE } \\
\hline Clitoria densiflora & & & $\mathrm{EX}^{* *}$ & & Ausência de novos registros nos últimos 50 anos \\
\hline Machaerium villosum & VU & & & & Perda de habitat \\
\hline \multicolumn{6}{|l|}{ MELIACEAE } \\
\hline Cedrela fissilis & $\mathrm{EN}$ & & & & Pedra de habitat, exploração \\
\hline
\end{tabular}

*Fontes: Mamede et al. (2007) e Martinelli e Moraes (2013).

**Embora conste como extinta na lista SMA-SP com base na justificativa de que não haveria coletas nos últimos 50 anos, registros recentes não corroboram a sua inclusão nessa categoria.

Clitoria densiflora é considerada extinta na lista SMA-SP devido à ausência de registros nos últimos 50 anos. Considerando que o ano de publicação dessa lista é 2004, não haveria registros a partir de 1954. Contudo, foram verificados 12 registros de coleta no Estado de São Paulo, sendo 11 efetuadas entre 1963 e 2013 (Species Link, 2014). Assim, a inclusão dessa espécie na categoria extinta não encontra respaldo nos registros de coleta, sendo necessária uma reavaliação do seu grau de ameaça por meio da atualização da lista SMA-SP.

As espécies ameaçadas em nível mundial (lista IUCN) e nacional (lista MMA) não se encontram ameaçadas em nível estadual (lista SMA-SP), o que indica uma condição mais favorável para essas espécies no Estado, condição essa corroborada pela constatação da ocorrência das referidas espécies na EEcA. Por outro lado, apenas uma espécie ameaçada (Clitoria densiflora) foi registrada na Estação com base na lista estadual. É possível que o histórico de uso do solo na EEcA, praticamente a totalidade da área ocupada com plantios de eucalipto cujo corte se estendeu por décadas, findando apenas em 2010, não seja compatível com as exigências, em termos de qualidade de habitat, de espécies ameaçadas de extinção em nível estadual. Isso não significa, contudo, que tais espécies não poderão se estabelecer espontaneamente com o passar do tempo, tampouco que não poderão ser reintroduzidas na área, sendo esta medida uma das ações de conservação de espécies ameaçadas passíveis de serem adotadas (ver Martinelli e Moraes, 2013). Por outro lado, é possível que fururas atualizações da lista SMA-SP venham a indicar mais espécies que ocorrem na EEcA como ameaçadas. 
Rourea pseudospadicea, além de ameaçada de extinção, também se enquadra na lista de espécies raras da Conservação Internacional - Brasil (CI-Brasil) (Giulietti et al., 2009). A espécie é restrita ao Estado de São Paulo e apresenta uma Área de Ocupação de apenas $12 \mathrm{~km}^{2}$ (Martinelli e Moraes, 2013). A presença dessa espécie motivou a definição de uma das "Áreas Chave para a Biodiversidade" (ACB) no Estado, com aproximadamente 124.000 ha, na região do município de Guareí (Giulietti et al., 2009). As ACBs são sítios definidos com base em endemismos e que apresentam relevância global para a conservação, demandando a criação de áreas protegidas (Giulietti et al., 2009).

\subsection{Proposta de Zoneamento com Base no Tema Vegetação}

As discussões do zoneamento tiveram como base o mapeamento da vegetação e os trabalhos de campo. Após a elaboração do mapa preliminar, foi efetuado um trabalho de campo complementar para que fossem efetuados os ajustes necessários (Figura 15, Tabela 4).

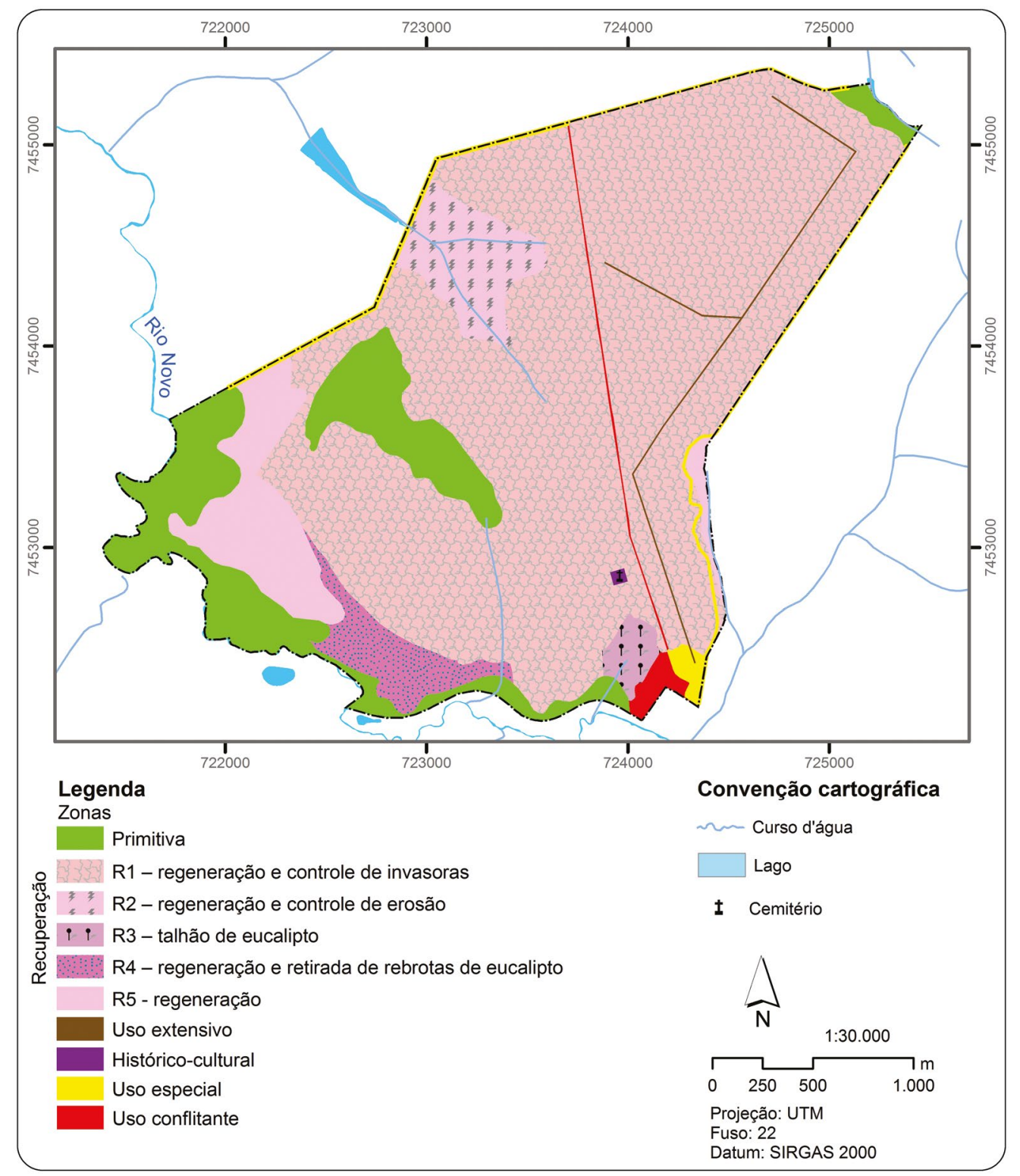

Figura 15. Zonas de manejo da Estação Ecológica de Avaré - SP, baseadas nas características da vegetação.

Figure 15. Management zones of the Avaré Ecological Station - SP, based on the vegetation characteristics. 
CIELO-FILHO, R. et al. Vegetação da Estação Ecológica de Avaré

Tabela 4. Zonas de manejo da Estação Ecológica de Avaré - SP, com base no tema vegetação.

Table 4. Management zones of the Avaré Ecological Station - SP, based on the vegetation theme.

\begin{tabular}{lll}
\hline Zonas de Manejo & Área (ha) & Área (\%) \\
\hline Primitiva & 94,03 & 13,05 \\
Recuperação & 611,00 & 84,81 \\
$\quad$ R1 - regeneração e controle de invasoras & 503,09 & 69,83 \\
R2 - regeneração e controle de erosão & 32,07 & 4,45 \\
R3 - talhão de eucalipto & 7,27 & 1,01 \\
$\quad$ R4 - regeneração e retirada de rebrotas de eucalipto & 22,42 & 3,11 \\
$\quad$ R5 - regeneração & 46,15 & 6,41 \\
Uso Extensivo & 1,67 & 0,23 \\
Uso Conflitante & 6,96 & 0,97 \\
Uso Especial & 6,22 & 0,86 \\
Histórico-Cultural & 0,50 & 0,07 \\
\hline Total geral & 720,43 & 100 \\
\hline
\end{tabular}

*Área de massa d'água: 0,05 ha $(0,01 \%)$.

Para fins de zoneamento, foram consideradas seis zonas de manejo: Primitiva, Recuperação, Histórico-Cultural, Uso Conflitante, Uso Extensivo e Uso Especial. A delimitação das Zonas Primitiva e de Recuperação foi baseada no histórico de uso e de manejo da área e no grau de conservação da vegetação, sendo o mapa de vegetação o instrumento norteador para a definição dessas zonas de manejo. As áreas em que a vegetação está mais próxima da composição natural primitiva foram incluídas na Zona Primitiva e aquelas cujo processo de regeneração ainda se encontra em fases mais iniciais foram definidas como Zonas de Recuperação.

\subsubsection{Zona Primitiva}

São áreas de Floresta Estacional Semidecidual Montana, Floresta Estacional Semidecidual Aluvial e de Savana Gramíneo-Lenhosa (Campo sujo), que se encontram em melhor estado de conservação. Ocorrem num total de 94,03 ha, correspondendo a 13,05\% da área total da Estação Ecológica.

\subsubsection{Zona de Recuperação}

São áreas de regeneração de Cerrado, de Floresta Estacional Semidecidual e de contato entre estas duas formações. O corte do eucalipto proporcionou, nesses locais, a regeneração natural e o contínuo restabelecimento da vegetação original. Ocupam 611 ha e $84,81 \%$ da área da Unidade de Conservação - UC. Nas áreas de Cerrado, é frequente a presença de espécies exóticas invasoras (braquiária - Urochloa brizantha e capim-gordura - Melinis minutiflora, entre outras), sendo necessário o manejo para o controle e a erradicação destas espécies.

Essa zona foi subdividida em cinco subzonas, de acordo com as suas características e diferentes indicações de manejo, a seguir:

- $\quad$ R1 - área de Cerrado (503,09 ha, 69,83\% da Estação Ecológica) em que foi identificada a necessidade de manejo e retirada de braquiária - Urochloa brizantha, capim-gordura Melinis minutiflora e brotações de eucalipto ainda existentes;

- $\quad$ R2 - área de Floresta Estacional Semidecidual (32,07 ha, 4,45\%) em que há problemas de erosão, havendo a necessidade de contenção da erosão e realização de plantios para a revegetação do local; 
- $\quad$ R3 - área de talhão de eucalipto $(7,27$ ha, 1,01\%) em que foi identificada a necessidade de remoção do talhão para a regeneração natural de Cerrado no local;

- $\quad$ R4 - área de regeneração da Floresta Estacional Semidecidual (22,42 ha e 3,11\%) em que é necessária a retirada de rebrotas de eucalipto;

- $\quad$ R5 - área de Floresta Estacional Semidecidual Aluvial (46,15 ha e 6,41\%) em que foi identificada a necessidade da regeneração natural (passiva) da vegetação, sem a adoção de medidas de manejo.

\subsubsection{Zona de Uso Extensivo}

Essa zona é composta pelas trilhas de visitação (1,67 ha e 0,23\%). Nessas trilhas, a visitação é monitorada e destinada à educação ambiental. As trilhas planejadas contemplam as áreas de Cerrado e de Floresta Estacional Semidecidual e utilizarão parte da estrutura de carreadores já existentes.

\subsubsection{Zona de Uso Conflitante}

As principais áreas identificadas como Zona de Uso conflitante (6,96 ha e 0,97\%) são:

- $\quad$ a estrada que atravessa a Estação Ecológica, dividindo-a ao meio, em que há um intenso fluxo de veículos, sobretudo caminhões, trafegando em alta velocidade. $\mathrm{O}$ alto tráfego de veículos pode acarretar atropelamentos da fauna silvestre da Estação Ecológica e facilitar a incidência de incêndios. Por isso, são necessárias medidas que ordenem o tráfego de veículos na Unidade de Conservação ou a indicação de uma nova rota que desvie esse tráfego do interior da UC;

- ocupações antigas provenientes do antigo Horto Andrada e Silva ainda existentes na área da Estação Ecológica.

\subsubsection{Zona Histórico-Cultural}

Nessa zona, localiza-se a igreja e seu salão de festas, e um antigo cemitério $(0,50$ ha e $0,07 \%)$. A igreja e o salão de festas são utilizados pela comunidade nos finais de semana e constituem uma atividade social importante na região, o que justifica sua manutenção. Quem administra a igreja é a matriz de Avaré. As atividades desenvolvidas nesses espaços devem se manter em conformidade com a proteção da Estação Ecológica. $\mathrm{Na}$ oficina de zoneamento, foi aventada a possibilidade da desafetação dessa área, o que implicaria na edição de uma lei específica para a alteração dos limites da Unidade de Conservação - UC. Essa proposta possivelmente não venha a ser necessária se houver normas adequadas de convivência e o compromisso com a proteção da UC.

Por sua vez, o cemitério atualmente é utilizado para práticas religiosas. $\mathrm{O}$ acendimento de velas, nessas práticas, tem causado focos de incêndio a partir deste local, portanto, apesar das suas características histórico-culturais, o cemitério também apresenta um caráter conflitante.

\subsubsection{Zona de Uso Especial}

Nessa zona, localiza-se a sede da vigilância da Estação Ecológica e vias de circulação internas e de interesse à administração da UC. Ocupa 6,22 ha e 0,86\% da Estação Ecológica.

A estrada principal, que atravessa a unidade, e parte dos carreadores também possuem esse caráter, uma vez que viabilizam a circulação de funcionários no local para o desenvolvimento das atividades previstas nos programas de manejo da UC. Essas áreas foram alocadas em outras zonas devido a outras características que possuem, por exemplo, a maioria dos carreadores está na Zona de Recuperação e a estrada principal, na Zona de Uso Conflitante. 


\subsubsection{Zona de Interferência Experimental}

Não foi definida uma zona de interferência experimental, embora esta seja prevista no Sistema Nacional de Unidades de Conservação - SNUC. Na oficina de zoneamento, foi indicado que eventuais áreas de interferência experimental poderão ocorrer na UC, exceto na sua Zona Primitiva, mas serão definidas mediante a elaboração de projetos de pesquisa e a análise e autorização do Instituto Florestal.

\subsection{Síntese das Recomendações de Manejo da Estação Ecológica}

Em alguns trechos da Estação ainda existem cepas de eucalipto que apresentam brotações que necessitam ser cortadas, assim como há indivíduos de Pinus que necessitam ser urgentemente erradicados pelo grande potencial de invasão que espécies deste gênero apresentam.

Espécies herbáceas exóticas (braquiária - Urochloa brizantha, capim-gordura Melinis minutiflora) e espécies-problema (samambaia-do-campo - Pteridium arachnoideum, capim-sapé - Imperata brasiliensis) estão presentes, são abundantes e competem com as nativas, necessitando ser monitoradas e manejadas para seu controle.

A EEcA abriga populações de espécies raras e ameaçadas que necessitam de monitoramento para a avaliação da necessidade de manejo. Por outro lado, há necessidade de intensificação dos esforços de coleta na Unidade visando ao conhecimento mais acurado sobre sua flora.

A estrada principal, que atravessa a Unidade de Conservação, é uma ameaça, pois diariamente trafegam caminhões pesados favorecendo a ocorrência de incêndios e a contaminação por espécies invasoras. Assim, faz-se necessário que se ordene o tráfego na Estação Ecológica, buscando rotas alternativas, mormente para os veículos pesados.

Outra origem dos incêndios é o uso de velas em práticas religiosas no antigo cemitério já desativado. A Savana Gramíneo-Lenhosa apresenta um predomínio da vegetação herbácea, grande biomassa de gramíneas e alta flamabilidade nas épocas secas do ano. Os aceiros entre a Estação Ecológica e o cemitério e áreas agrícolas ao seu redor necessitam ser mantidos regularmente.

No entorno da Estação, há produtores rurais que se utilizam da aviação agrícola para a aplicação de agrotóxicos. Essas substâncias prejudicam a biota nas bordas da Unidade. A utilização de defensivos agrícolas nas culturas do entorno deve ser disciplinada para evitar tais danos.

A Estação Ecológica é excessivamente cortada por vias de circulação, que eram as antigas ruas entre os talhões de eucalipto. Uma Unidade de Conservação não deve ser tão recortada e ter seu acesso tão facilitado, uma vez que fica exposta a ações antrópicas irregulares como a caça e a coleta de várias espécies vegetais. Assim, recomenda-se que sejam definidas as vias que serão mantidas para uso da Unidade nas atividades de proteção, educação ambiental, administração e pesquisa.

\section{AGRADECIMENTOS}

Somos gratos aos funcionários da Floresta Estadual de Avaré pelo apoio logístico e nas atividades de campo, bem como ao técnico de herbário Ernane Lino da Silva; à estagiária e acadêmica de Biologia Michelle Marques pelo apoio no processamento e montagem do material botânico; à acadêmica de Biologia Bruna Ferratto pelo auxílio no manuseio do material botânico; ao Pesquisador Científico Claudio de Moura pela cuidadosa relatoria; aos dois revisores anônimos pelas ótimas sugestões e à Yara Cristina Marcondes pela revisão final do texto. Gostaríamos também de expressar nosso agradecimento especial aos taxonomistas especialistas que contribuíram para a realização deste trabalho. 


\section{REFERÊNCIAS BIBLIOGRÁFICAS}

AGUIAR, L.M.S. et al. Cerrado: ecologia e caracterização. Brasília, DF: Embrapa, 2004. 249 p.

ALONSO-AMELOT, M.E. et al. Bracken adaptation mechanisms and xenobiotic chemistry. Pure and Applied Chemistry, v. 73, n. 3, p. 549-553, 2001.

ARRUDA, M.B. et al. Ecorregiões, unidades de conservação e representatividade ecológica do bioma cerrado. In: SANO, S.M.; ALMEIDA, S.P.; RIBEIRO, J.F. (Ed.). Cerrado: ecologia e flora. Brasília, DF: Empresa Brasileira de Pesquisa Agropecuária - Embrapa, 2008. p. 229-272.

ARZOLLA, F.A.R.P. et al. Mapeamento e composição florística dos principais tipos vegetacionais. In: ARZOLLA, F.A.R.D.P.; VILELA, F.S.P. (Coord.). Proposta para criação da Estação Ecológica de Avaré. São Paulo: Secretaria do Meio Ambiente: Instituto Florestal, 2010. p. 15-24.

; VILELA, F.E.S.P (Coord.). Proposta para a criação da Estação Ecológica de Avaré. São Paulo: Secretaria do Meio Ambiente: Instituto Florestal, 2010. 61 p.

BAITELLO, J.B. et al. Parque Estadual do Juquery: refúgio de Cerrado no Domínio Atlântico. IF Série Registros, v. 50, p. 1-46, 2013.

BARUCH, Z.; LUDLOW, M.M.; DAVIS, R. Photosynthetic responses of native and introduced C4 grasses from Venezuelan savannas. Oecologia, v. 67, n. 3, p. 388-393, 1985.

BRANDÃO, M. et al. Cobertura vegetal no município de Sete Lagoas - MG. Dapne, v. 3, n. 2, p. 21-38, 1993.

BRANDO, P.M.; DURIGAN, G. Changes in cerrado vegetation after disturbance by frost (São Paulo State, Brazil). Plant Ecology, v. 175, n. 175, p. 205-215, 2004.

BRASIL. Lei $\mathrm{n}^{0}$ 9.605, de 12 de fevereiro de 1998. Dispõe sobre as sanções penais e administrativas derivadas de condutas e atividades lesivas ao meio ambiente, e dá outras providências. Diário Oficial da União, v. 136, n. 31-E, 13 fev. 1998. Seção 1, p. 1-5.

Lei $\mathrm{n}^{\circ}$ 9.985, de 18 de julho de 2000. Regulamenta o art. 225, $\S 1^{\circ}$, incisos I, II, III e VII da Constituição Federal, institui o Sistema Nacional de Unidades de Conservação da Natureza e dá outras providências. Diário Oficial da União, Poder Executivo, v. 138, n. 138-E, 19 jul. 2000a. Seção 1, p. 45.

. Decreto $n^{0} 3.607$, de 21 de setembro de 2000. Dispõe sobre a implementação da Convenção sobre Comércio Internacional das Espécies da Flora e Fauna Selvagem em Perigo de Extinção - CITES, e dá outras providências. Diário Oficial da União, v. 138, n. 184-E, 22 set. 2000b. Seção 1, p. 18.

Ministério do Meio Ambiente - MMA. Portaria $\mathrm{n}^{0}$ 443, de 17 de dezembro de 2014. Reconhece como espécies da flora brasileira ameaçadas de extinção aquelas constantes da "Lista Nacional Oficial de Espécies da Flora Ameaçadas de Extinção". Disponível em: $<$ http://sintse.tse.jus.br/documentos/2014/Dez/18/portaria-no-443-de-17-de-dezembro-de-2014>. Acesso em: 22 abr. 2015.

CASTRO, A.A.J.F.; MARTINS, F.R. Cerrados do Brasil e do Nordeste: caracterização, área de ocupação e considerações sobre a sua fitodiversidade. Pesquisa em Foco, v. 7, n. 9, p. 147-160, 1999.

CAVASSAN, O. O Cerrado do Estado de São Paulo. In: KLEIN, A.L. (Org.). Eugen Warming e o cerrado brasileiro um século depois. São Paulo: Editora UNESP, 2002. p. 93-106.

CIELO-FILHO, R. et al. A vegetação da Estação Ecológica de Itapeva: subsídios para o Plano de Manejo. IF Série Registros, v. 46, p. 1-86, 2011.

Aspectos florísticos da Estação Ecológica de Itapeva: uma unidade de conservação no limite meridional do bioma Cerrado. Biota Neotropica, v. 12, n. 2, p. 147-166, 2012. 
COUTINHO, L.M. O conceito de Cerrado. Revista Brasileira de Botânica, v. 1. n. 1, p. 17-23, 1978.

D'ANTONIO, C.M.; VITOUSEK, P.M. Biological invasions by exotic grasses, the grass/fire cycle, and global change. Annual Review of Ecology and Systematics, v. 23, n. 1, p. 63-87, 1992.

DURIGAN, G. et al. The vegetation of priority areas for cerrado conservation in São Paulo state, Brazil. Edinburgh Journal of Botany, v. 60, n. 2, p. 217-241, 2003.

. Observation on the southern cerrados and their relationships with the core area. In: PENNINGTON, T.; GWILYM, P.L.; RATTER, F.A. (Org.). Neotropical Savannas and Dry Forests: diversity, biogeography and conservation. London: Taylor \& Francis, 2006. p. 67-77.

. (Coord.). Plano de manejo da Estação Ecológica de Assis. São Paulo: Instituto Florestal, 2008. 172 p.

.; SIQUEIRA, M.F.; FRANCO, G.A.D.C. Threats to the Cerrado remnants of the state of São Paulo, Brazil. Scientia Agricola, v. 64, p. 366-363, 2007.

. et al. Inventário florístico do cerrado da Estação Ecológica de Assis, SP. Hoehnea, v. 26, n. 2, p. $149-172,1999$.

et al. Plantas do Cerrado paulista: imagens de uma paisagem ameaçada. São Paulo: Páginas \& Letras, 2004. 475 p.

FIDALGO, O.; BONONI, V.L.R. (Coord.). Técnicas de coleta, preservação e herborização de material botânico. São Paulo: Instituto de Botânica, 1984. 62 p. (Manual, n. 4).

FILGUEIRAS, T.S. Herbaceous plant communities. In: OLIVEIRA, P.S.; MARQUIS, R.J. (Org.). The cerrados of Brazil: ecology and natural history of a neotropical savanna. New York: Columbia University Press, 2002. p. 121-139.

. Africanas no Brasil: gramíneas introduzidas da África. Cadernos de Geociências, v. 5, n. 1, p. 57-63, 1990.

. et al. Caminhamento: um método expedito para levantamentos florísticos qualitativos. Caderno de Geociências, v. 12, n. 1, p. 39-43, 1994.

FONTES, J.R.; SHIRATSUCHI, L.S. Manejo integrado de plantas daninhas em pastagens - Parte I. EMBRAPA: Artigos Técnicos. Disponível em: $<$ http://www.boletimpecuario.com.br/artigos/showartigo.php? arquivo=artigo470.txt\&tudo $=$ sim. $>$ Acesso em: 19 nov. 2014.

FORZZA, R.C. et al. Lista de espécies da flora do Brasil. Jardim Botânico do Rio de Janeiro, 2015. Disponível em: <http://floradobrasil.jbrj.gov.br/jabot/floradobrasil/FB128482>. Acesso em: 16 abr. 2015.

FREITAS, G.K. Invasão biológica pelo capim-gordura (Melinis minutiflora Beauv) em um fragmento de cerrado (A.R.I.E. Cerrado Pé-de-Gigante, Santa Rita do Passa Quatro, SP). 1999. 152 f. Dissertação (Mestrado em Biociências) - Instituto de Biociências da Universidade de São Paulo, São Paulo.

GALANTE, M.L.V.; BESERRA, M.M.L.; MENEZES, E.O. Roteiro metodológico de planejamento: parque nacional, reserva biológica, estação ecológica. Brasília, DF: IBAMA, 2002. 136 p.

GIULIETTI, A.M. et al. (Org.). Plantas raras do Brasil. Belo Horizonte: Conservação Internacional, 2009. $496 \mathrm{p}$.

HIGGINS, S.I.; RICHARDSON, D.M. Pine invasions in the southern hemisphere: modelling interactions between organism, environment and disturbance. Plant Ecology, v. 135, p. 79-93, 1998.

HOFFMANN, W.A.; HARIDASAN, M. The invasive grass, Melinis minutiflora, inhibits tree regeneration in a Neotropical savanna. Austral Ecology, v. 33, n. 1, p. 29-36, 2008. 
HUGHES, F.; VITOUSEK, P.M.; TUNISON, T. Alien grass invasion and fire in the seasonal submontane zone of Hawai. Ecology, v. 72, n. 2, p. 743-746, 1991.

INSTITUTO BRASILEIRO DE GEOGRAFIA E ESTATÍSTICA - IBGE. Manual técnico da vegetação brasileira: sistema fitogeográfico, inventário das formações florestais e campestres, técnicas e manejo de coleções botânicas, procedimento para mapeamento. 2. ed. rev. e ampl. Rio de Janeiro: IBGE - Coordenação de Recursos Naturais e Estudos Ambientais, 2012. 272 p.

INSTITUTO DE PESQUISAS TECNÓLOGICAS DO ESTADO DE SÃO PAULO - IPT. Mapa geológico do Estado de São Paulo. São Paulo, 1981. 126 p. (Série Monografias, n. 6, v. 1).

INTERNATIONAL UNION FOR CONSERVATION OF NATURE - IUCN. IUCN Red List categories and criteria version. 3.1. Gland: IUCN Species Survival Commission, 2001. 35 p.

The IUCN red list of threatened species. Disponível em: <www.iucn.org>. Acesso em: 26 fev. 2014.

IVANAUSKAS, N.M.; RODRIGUES, R.R.; NAVE, G. Aspectos ecológicos de um trecho de floresta de brejo em Itatinga, SP: florística, fitossociologia e seletividade de espécies. Revista Brasileira de Botânica, v. 20, n. 2, p. 139-153, 1997.

KLINK C.A.; MACHADO R.B. A conservação do Cerrado brasileiro. Megadiversidade, v. 1, n. 1, p. $147-155,2005$.

KRONKA, F.J.N. et al. Áreas de domínio do Cerrado no Estado de São Paulo. São Paulo: Imprensa Oficial, 1998. 84 p.

et al. Inventário florestal da vegetação natural do Estado de São Paulo. São Paulo: Imprensa Oficial, 2005. $200 \mathrm{p}$.

LEITÃO-FILHO, H. F. Aspectos taxonômicos das florestas do Estado de São Paulo. In: SIMPÓSIO SOBRE ESSÊNCIAS NATIVAS, 2., 1982, São Paulo: UNIPRESS, 1982. Anais... (Revista do Instituto Florestal, v. 16-A, Pt. 1, p. 197-206, 1982, Edição Especial).

LUEDER, D.R. Aerial photographic interpretation: principles and applications. New York: McGraw-Hill, 1959. 462 p.

MAMEDE, M.C.H. et al. Livro vermelho das espécies vegetais ameaçadas do Estado de São Paulo. São Paulo: Instituto de Botânica, 2007. 165 p.

MARTINELli, G.; MORAES, M.A. (Org.). Livro vermelho da flora do Brasil. Rio de Janeiro: Instituto de Pesquisas Jardim Botânico do Rio de Janeiro, 2013. 1100 p.

MARTINS, C.R. et al. Monitoramento e controle da gramínea invasora Melinis minutiflora (capim-gordura) no Parque Nacional de Brasília, Distrito Federal. In: CONGRESSO BRASILEIRO DE UNIDADES DE CONSERVAÇÃO, 4., 2004, Curitiba. Anais... Natal: Fundação O Boticário de Proteção à Natureza, Rede Nacional Pró-Unidades de Conservação, 2004. Seminário 2, p. 85-96.

MEIRA-NETO, J.A.A.; MARTINS, F.R.; VALENTE, G.E. Composição florística e espectro biológico na Estação Ecológica de Santa Bárbara, estado de São Paulo, Brasil. Revista Árvore, v. 31, n. 5, p. $907-922,2007$.

MELO, A.C.G.; DURIGAN, G. (Coord.). Plano de manejo da Estação Ecológica de Santa Bárbara. São Paulo: Instituto Florestal, 2011. 222 p.

MENDONÇA, R.C. et al. Flora vascular do bioma Cerrado: checklist com 12.356 espécies. In: SANO, S.M.; ALMEIDA, S.P.; RIBEIRO, J.F. (Ed.). Cerrado: ecologia e flora. Brasília, DF: Embrapa Informação e Tecnologia, 2008. v. 2, p. 423-1279. 
MISSOURI BOTANICAL GARDEN - MOBOT. W3TROPICOS. The Missouri Botanical Garden's VAST (Vascular Tropicos) nomenclatural database and associated authority files. Disponível em: $<$ http://www.mobot.mobot.org/W3T/Search/vast.html>. Acesso em: 30 mar. 2014.

MITTERMEIER, R.A. et al. Hotspots revisited: earth's biologically richest and most endangered terrestrial ecoregions. Mexico: CEMEX \& Agrupacion Sierra Madre, 2005. 392 p.

PIVELLO, V.R.; SHIDA, C.N.; MEIRELLES, S.T. Alien grasses in Brazilian savannas: a threat to biodiversity. Biodiversity \& Conservation, v. 8, n. 9, p. 1281-1294, 1999.

RASSMUSSEN, L.H. Ptaquiloside - an environmental hazard? Occurrence and fate of a bracken (Pteridium sp.) toxin in terrestrial environments. 2003. $283 \mathrm{f}$. Thesis (Ph.D. Thesis in Natural Sciences) Chemistry Department - The Royal Veterinary and Agricultural University, Frederiksberg.

RATTER, J.A.; BRIDGEWATER, S.; RIBEIRO, J.F. Analysis of the floristic composition of the Brazilian cerrado vegetation. III. Comparison of the woody vegetation of 376 areas. Edinburgh Journal of Botany, v. 60, n. 1, p. 57-109, 2003.

RIBEIRO, J.F.; WALTER, B.M.T. As principais fitofisionomias do bioma Cerrado. In: SANO, S.M.; ALMEIDA, S.P.; RIBEIRO, J.F. (Ed.). Cerrado: ecologia e flora. Brasília, DF: Empresa Brasileira de Pesquisa Agropecuária - Embrapa, 2008. p. 151-199.

RODRIGUES, R.R.; BONONI, V.L.R. (Org.). Diretrizes para a conservação e restauração da biodiversidade no Estado de São Paulo. São Paulo: Instituto de Botânica, 2008. 227 p.

ROMARIZ, D.A. Aspectos da vegetação do Brasil. São Paulo: Edição da Autora, 1996. 60 p.

ROSSATO, D.R.; TONIATO, M.T.Z.; DURIGAN, G. Flora Fanerogâmica não arbóreo do Cerrado na Estação Ecológica de Assis Estado de São Paulo. Revista Brasileira de Botânica, v. 31, n. 3, p. 409-424, 2008.

SÃO PAULO (Estado). Secretaria do Meio Ambiente. Resolução SMA no 48, de 21 de setembro de 2004. Lista oficial das espécies da flora do estado de São Paulo ameaçadas de extinção. Disponível em: <www.ibot.sp.gov.br>. Acesso em: 14 ago. 2014.

Decreto $\mathrm{n}^{\mathrm{o}}$ 56.616, de 28 de dezembro de 2010. Cria a Estação Ecológica de Avaré na área que compõe o Horto Florestal de Andrada e Silva, Município de Avaré, em terras que estão sob posse e domínio da Fazenda Pública do Estado de São Paulo, e dá providências correlatas. Disponível em: <http:/www.al.sp.gov.br/repositorio/legislacao/decreto/2010/decreto-56616-28.12.2010.html>. Acesso em: 14 ago. 2014.

SENTELHAS, P.C. et al. Balanços hídricos climatológicos de $\mathbf{5 0 0}$ localidades brasileiras. Disponível em: $<$ http://www.lce.esalq.usp.br/nurma.html >. Acesso em: 6 abr. 2010.

SHAHIN, M. et al. Bracken carcinogens in humam diet. Mutation Research, v. 443, n. 1/2, p. 69-79, 1999.

SILVA, D.A.; KANASHIRO, M.M. Caracterização do meio físico. In: ARZOLLA, F.A.R.D.P.; VILELA, F.S.P. (Coord.). Proposta para criação da Estação Ecológica de Avaré. São Paulo: Secretaria do Meio Ambiente: Instituto Florestal, 2010. p. 2-14

SOUZA, V.C.; LORENZI, H. Botânica sistemática: guia ilustrado para identificação das famílias de Fanerógamas nativas e exóticas no Brasil, baseado em APGIII. 3. ed. Nova Odessa: Instituto Plantarum de Estudos da Flora, 2012. 768 p.

SPECIES LINK. Sistema de informação distribuído para recuperação de dados de acervos de coleções biológicas e de observação em campo. Disponível em: <http://www.splink.cria.org.br/>. Acesso em: 14 ago. 2014. 
SPURR, S.H. Photogrammetry and photo-interpretation. New York: Ronald Press, 1960. 472 p.

TONIATO, M.T.Z.; LEITÃO-FILHO, H.F.; RODRIGUES, R.R. Fitossociologia de um remanescente de floresta higrófila (mata de brejo) em Campinas, SP. Revista Brasileira de Botânica, v. 21, n. 2, p. 197-210, 1998.

VELOSO, H.P.; GÓES-FILHO, L. Fitogeografia brasileira: classificação fisionômico-ecológica da vegetação neotropical. Salvador: Ministério das Minas e Energia, Divisão de Vegetação, Projeto RADAMBRASIL, 1982. 86 p. (Projeto RADAMBRASIL, Série Vegetação 1).

VICTOR, M.A.M. et al. Cem anos de devastação: revisada 30 anos depois. Brasília, DF: Ministério do Meio Ambiente, Secretaria de Biodiversidade e Florestas, 2005. 72 p.

WANDERLEY, M.G.L. et al. Checklist das Spermatophyta do Estado de São Paulo, Brasil. Biota Neotropica, v. 11, n. 1a, p. 193-390, 2011.

ZALBA, S.M.; CUEVAS, Y.A.; BOÓ, R.M. Invasion of Pinus halepensis Mill. following a wildfire in an Argentine grassland nature reserve. Journal of Environmental Management, v. 88, p. 539-546, 2008.

.; ZILLER, S.R. Introdução às invasões biológicas. In: BRAND, K.; MATTHEWS, S. (Ed.). América

do Sul invadida: a crescente ameaça das espécies exóticas invasoras. Nairobi: Secretaria do GISP - Programa Global de Espécies Invasoras, 2005. p. 4-5.

ZENNI, R.D.; ZILLER, S.R. An overview of invasive plants in Brazil. Revista Brasileira de Botânica, v. 34, n. 3, p. 431-446, 2011.

ZILLER, S.R. Plantas exóticas invasoras: a ameaça da contaminação biológica. Ciência Hoje, v. 178, p. 77-79, 2001. 